\title{
Development of Therapeutic Antibodies and Modulating the Characteristics of Therapeutic Antibodies to Maximize the Therapeutic Efficacy
}

\author{
Seung Hyun Kang and Chang-Han Lee
}

Received: 9 June 2020 / Revised: 13 August 2020 / Accepted: 17 August 2020

(C) The Korean Society for Biotechnology and Bioengineering and Springer 2021

\begin{abstract}
Monoclonal antibodies (mAb) have been used as therapeutic agents for various diseases, and immunoglobulin $\mathrm{G}(\mathrm{IgG})$ is mainly used among antibody isotypes due to its structural and functional properties. So far, regardless of the purpose of the therapeutic antibody, wildtype IgG has been mainly used, but recently, the engineered antibodies with various strategies according to the role of the therapeutic antibody have been used to maximize the therapeutic efficacy. In this review paper, first, the overall structural features and functional characteristics of antibody IgG, second, the old and new techniques for antibody discovery, and finally, several antibody engineering strategies for maximizing therapeutic efficacy according to the role of a therapeutic antibody will be introduced.
\end{abstract}

Keywords: therapeutic antibody, antibody engineering, Fc engineering, bispecific antibody

\section{Introduction}

After the first US Food and Drug Administration (FDA) approved monoclonal antibody ( $\mathrm{mAb}$ ), for 30 years, mAbs

Seung Hyun Kang, Chang-Han Lee

Department of Pharmacology, Seoul National University College of Medicine, Seoul 03080, Korea

Chang-Han Lee*

Department of Biomedical Sciences, Seoul National University College of Medicine, Seoul 03080, Korea

Wide River Institute of Immunology (WRII) SNU, Hongcheon 25159, Korea

SNU Dementia Research Center, Seoul National University College of Medicine, Seoul 03080, Korea

Tel: +82-2-740-8287

E-mail: chlee-antibody@snu.ac.kr become a valuable mainstream in the development of drugs against diverse diseases. All aspects of the development of therapeutic $\mathrm{mAbs}$ have matured from clinical research to commercialization strategies [1-6]. FDA and European Medicines Agency (EMA) approved $36 \mathrm{mAb}$ drugs from 2013 to 2017, and the FDA approved 23 new mAbs in the last two years (2018-2020.04) (Table 1). The total number of $\mathrm{mAb}$ drugs approved by the FDA or EMA continues to grow, with new projects continually evolving from proof of concept to new goals and new technologies. We are experiencing the golden age of $\mathrm{mAb}$ drug development. In particular, we have witnessed recent breakthroughs in the anti-cancer antibodies' development, including cancertargeting antibody, immune checkpoint blockade, etc. [5,7]. Anti-cancer mAbs can induce immune responses in various ways, including directly targeting malignant cells, delivering the effector cells' cytotoxicity, and retargeting cellular immunity towards malignant cells $[2,5,6,8,9]$. These functions can be affected by the characteristics of mAb such as antigen specificity, overall structure, affinity against an antigen, and immune response by antibody $\mathrm{Fc}$ domain. Immunoglobulin $\mathrm{G}$ ( $\mathrm{IgG}$ ) isotype is the most widely used antibody isotype, and its various forms are used for therapeutic purposes. IgG has numerous roles in the human immune defense system and is increasingly used as a key linker between adaptive immunity and innate immunity with great success [10].

However, current antibody therapies still need to be improved, so diverse efforts are being made to develop enhanced therapeutic mAbs [9,11-13]. This review addresses i) the overall characteristics of antibody IgG, ii) the efficient technics and methods to discover therapeutic antibodies, iii) antibody engineering to develop therapeutic antibodies. 
Table 1. FDA approved antibodies for recent 2 years (lists are from https://www.fda.gov/)

\begin{tabular}{|c|c|c|c|c|}
\hline Drug Name & Active Ingredient & Target & Approval Date & FDA-approved use on approval date* \\
\hline Sarclisa & Isatuximab & CD38 & $3 / 2 / 2020$ & Multiple myeloma \\
\hline Vyepti & eptinezumab-jjmr & $\begin{array}{l}\text { Calcitonin gene-related } \\
\text { peptide (CGRP) ligand }\end{array}$ & $2 / 21 / 2020$ & For the preventive treatment of migraine in adults \\
\hline Tepezza & teprotumumab-trbw & $\begin{array}{l}\text { Insulin-like growth factor } \\
1 \text { receptor (IGF-1R) }\end{array}$ & $1 / 21 / 2020$ & Thyroid eye disease \\
\hline Enhertu & $\begin{array}{l}\text { fam-trastuzumab } \\
\text { deruxtecan-nxki }\end{array}$ & HER2 & $12 / 20 / 2019$ & Metastatic breast cancer \\
\hline Padcev & enfortumab vedotin-ejfv & Nectin-4 & $12 / 18 / 2019$ & Refractory bladder cancer \\
\hline Adakveo & crizanlizumab-tmca & Selectin P & $11 / 15 / 2019$ & Painful complication of sickle cell disease \\
\hline Beovu & brolucizumab-dbll & $\begin{array}{l}\text { Vascular endothelial } \\
\text { growth factor (VEGF) }\end{array}$ & $10 / 7 / 2019$ & Wet age-related macular degeneration \\
\hline Polivy & $\begin{array}{l}\text { polatuzumab vedotin- } \\
\text { piiq }\end{array}$ & CD79B & $6 / 10 / 2019$ & $\begin{array}{l}\text { Relapsed or refractory diffuse large B-cell } \\
\text { lymphoma Adult patients }\end{array}$ \\
\hline Skyrizi & risankizumab-rzaa & Interleukin 23A (IL-23a) & $4 / 23 / 2019$ & $\begin{array}{l}\text { Moderate-to-severe plaque psoriasis adult } \\
\text { patients who are in the systemic therapy or light } \\
\text { therapy }\end{array}$ \\
\hline Evenity & romosozumab-aqqg & Sclerostin & 4/9/2019 & $\begin{array}{l}\text { Osteoporosis in postmenopausal women at high } \\
\text { risk of fracture }\end{array}$ \\
\hline Cablivi & caplacizumab-yhdp & von Willebrand factor & $2 / 6 / 2019$ & $\begin{array}{l}\text { Adult patients with acquired thrombotic } \\
\text { thrombocytopenic purpura (aTTP) }\end{array}$ \\
\hline Ultomiris & Ravulizumab & $\mathrm{C} 5$ & $12 / 21 / 2018$ & Paroxysmal nocturnal hemoglobinuria (PNH) \\
\hline Gamifant & $\begin{array}{l}\text { emapalumab- } \\
\text { lzsgemapalumab-lzsg }\end{array}$ & Interferon-gamma (IFN $\gamma)$ & $11 / 20 / 2018$ & $\begin{array}{l}\text { Primary hemophagocytic lymphohistiocytosis } \\
\text { (HLH) }\end{array}$ \\
\hline Libtayo & cemiplimab-rwlc & $\begin{array}{l}\text { Programmed death } 1(P D- \\
\text { 1) receptor }\end{array}$ & $9 / 28 / 2018$ & Cutaneous squamous cell carcinoma (CSCC) \\
\hline Emgality & galcanezumab-gnlm & CGRP & $9 / 27 / 2018$ & For the preventive treatment of migraine in adults \\
\hline Ajovy & fremanezumab-vfrm & CGRP & $9 / 14 / 2018$ & For the preventive treatment of migraine in adults \\
\hline Lumoxiti & $\begin{array}{l}\text { moxetumomab } \\
\text { pasudotox-tdfk }\end{array}$ & $\mathrm{CD} 22$ & $9 / 13 / 2018$ & Hairy cell leukemia \\
\hline Takhzyro & Lanadelumab & Kallikrein & $8 / 23 / 2018$ & Types I and II hereditary angioedema \\
\hline Poteligeo & mogamulizumab-kpkc & C-C chemokine receptor 4 & $8 / 8 / 2018$ & Two rare types of non-Hodgkin lymphoma \\
\hline Aimovig & erenumab-aooe & CGRP receptor & $5 / 17 / 2018$ & For the preventive treatment for migraine \\
\hline Crysvita & burosumab-twza & $\begin{array}{l}\text { Fibroblast growth factor } \\
23 \text { (FGF23) }\end{array}$ & $4 / 17 / 2018$ & $\begin{array}{l}\text { Adults and children ages } 1 \text { year and older with x- } \\
\text { linked hypophosphatemia (XLH), a rare, } \\
\text { inherited form of rickets }\end{array}$ \\
\hline Ilumya & tildrakizumab & IL-23 & $3 / 20 / 2018$ & $\begin{array}{l}\text { Moderate-to-severe plaque psoriasis adult } \\
\text { patients who are in the systemic therapy or light } \\
\text { therapy }\end{array}$ \\
\hline Trogarzo & ibalizumab-uiyk & CD4 & $3 / 6 / 2018$ & HIV patients who have limited treatment options \\
\hline
\end{tabular}

\section{Antibody Structure and Function}

Antibody IgG is composed of two heavy chains connected by disulfide bonds at hinge regions and two light chains. The heavy chain is composed of four domains of $\mathrm{VH}-$ $\mathrm{CH} 1-\mathrm{CH} 2-\mathrm{CH} 3$, and there is a hinge, which is a very flexible linker between $\mathrm{CH} 1$ and $\mathrm{CH} 2$ domains $[14,15]$. The light chain consists of two domains, VL and CL, and the last amino acid of CL, cys, forms a disulfide bond with the heavy chain $\mathrm{CH} 1$ domain. Each domain belongs to the immunoglobulin (Ig) domain family, and the general Ig domain consists of $7 \beta$ strands and a loop connecting each $\beta$ strand (Fig. 1A). In the Ig domain of VH differ with that of the VL domain, both domains contain two short $A \beta$ strands (A1 and $\mathrm{A} 2$ ) and additional $\mathrm{C} \beta$ strands $\left(\mathrm{C}^{\prime}\right.$ and $\left.\mathrm{C}^{\prime \prime}\right)$ comparing with other Ig domain [14]. Some of the loops between $\beta$ strands in VH and VL domain are complementaritydetermining regions (CDRs; $\mathrm{BC}$ loop: $\mathrm{CDR} 1, \mathrm{C}^{\prime} \mathrm{C}^{\prime \prime}$ loop: CDR2, and FG loop: CDR3) which are hypervariable regions and responsible for direct physical contact with an antigen $[14,15]$. Six CDRs, three from each heavy and light chain, provide a unique antigen specificity of antibodies and act like fingers indicating the intensity of antigenbinding $[14,15]$. Notably, the VH-CH1 / VL-CL portion having antigen-binding properties is referred to as fragment antigen-binding $(\mathrm{Fab})$ regions. The constant region contains 
A

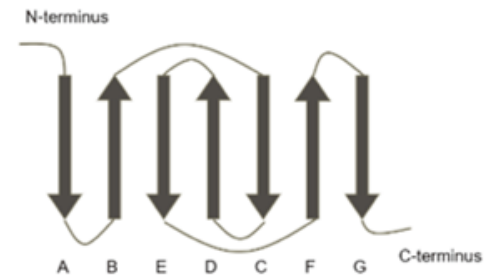

B

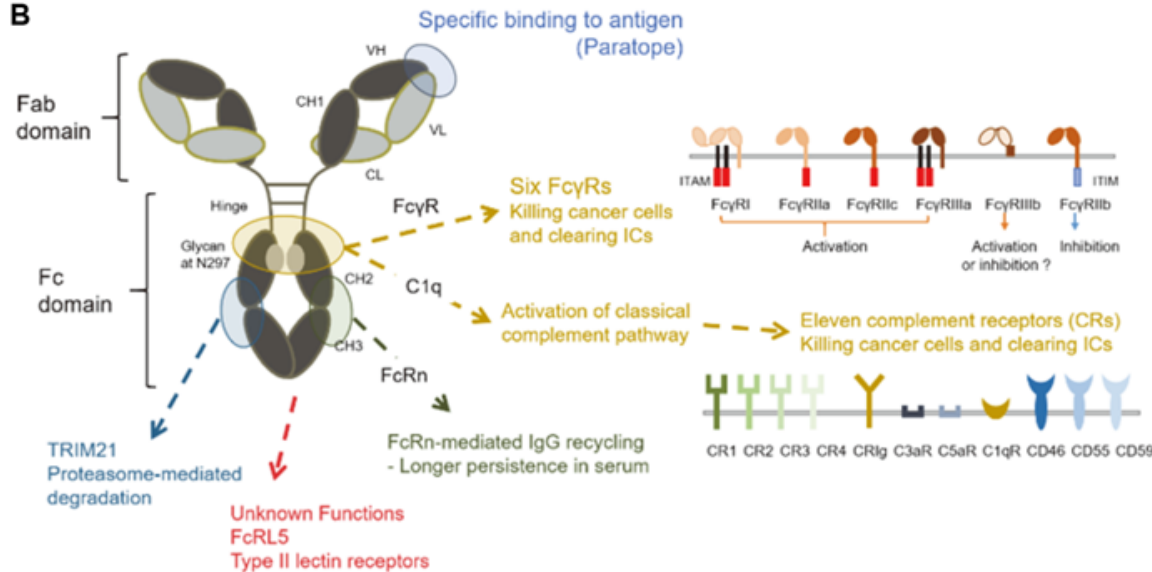

C

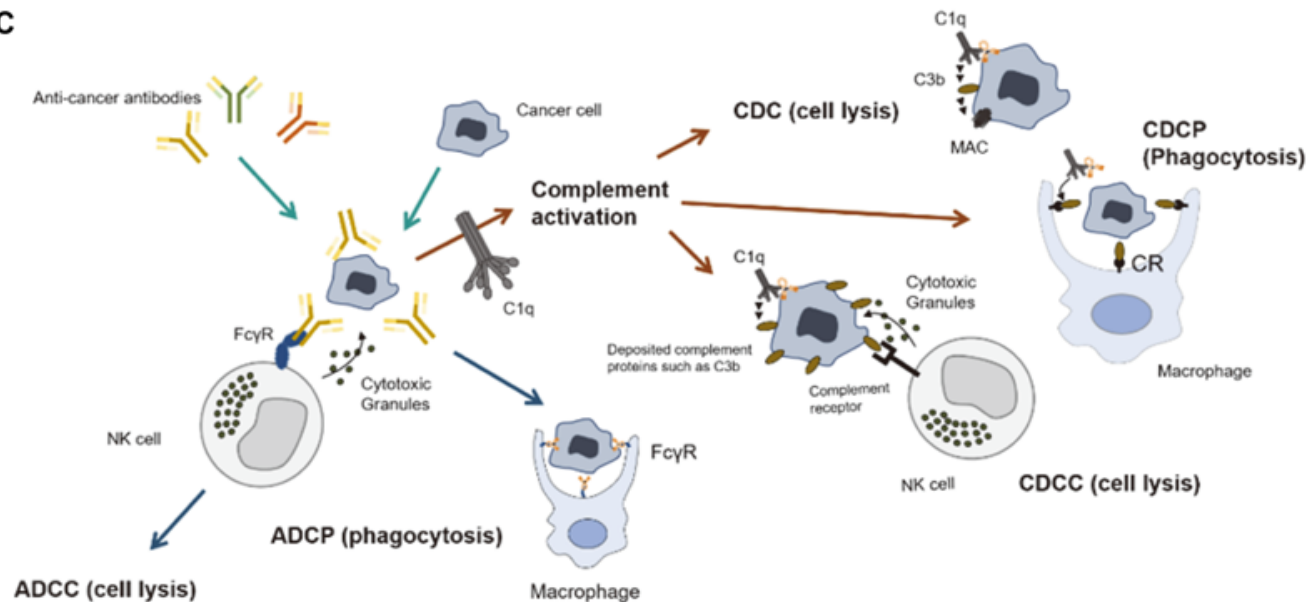

ADCC (cell lysis)

Macrophage

Fig. 1. Antibody nomenclature and structure. (A) The secondary structure of the general immunoglobulin domain. (B) Schematic diagram depicting the basic structure of the antibody IgG. IgG consists of two light chains and two heavy chains. The light chain (shown in light grey) consists of a variable (VL) and a constant (CL) domain, while the heavy chain (shown in dark grey) consists of a variable $(\mathrm{VH})$ domain and three constant domains $(\mathrm{CH} 1, \mathrm{CH} 2$, and $\mathrm{CH} 3)$. The complementarity determining regions (CDR) in variable domains govern antigen specificity, and the $\mathrm{Fc}$ domain modulates diverse immune functions through binding to $\mathrm{Fc} \gamma \mathrm{Rs}$, complement $\mathrm{Clq}$, neonatal Fc receptor (FcRn), TRIM21, etc. (C) Immune complexes are capable to activate diverse effector functions, such as Fc $\gamma \mathrm{R}-\mathrm{mediated}$ ADCC and ACDP and complement mediated CDC, CDCC, and CDCP.

nearly identical amino acid sequences in all antibodies that are categorized as the same isotypes, but it differs in different isotypes. The isotype of antibodies defines the class of a heavy chain, and there are five isotypes of mammalian Ig heavy chain described by Greek letters: $\alpha$, $\delta, \varepsilon, \gamma$, and $\mu$. These chains are respectively found in IgA, $\mathrm{IgD}, \operatorname{IgE}, \mathrm{IgG}$, and IgM antibodies. Moreover, heavy chains $\gamma, \alpha$, and $\delta$ carry a constant region consist of three tandem Ig domains and a hinge region that giving flexibility. The heavy $\mu$ and $\varepsilon$ have a constant region composed of four immunoglobulin domains [14,15], and the antibody's constant domain determines the isotype of the antibody and even plays a critical role in the immune system.

The IgG Fc domain, which is glycosylated at Asn297, has a wide variety of functions because it recruits many Fc binding proteins, including six $F c \gamma$ receptors (Fc $\gamma R s$ ), complement $\mathrm{C} 1 \mathrm{q}, \mathrm{Fc}$ receptor-like protein 5 (FcRL5), neonatal Fc receptor (FcRn), tripartite motif containing-21 (TRIM21), and type II lectin receptors (Fig. 1B) [3,16-22]. The interaction of antibody Fc domains with Fc binding proteins results in numerous cell phenotypes collectively referred to as "effector functions" [3,16,17]. The effector functions are the main mechanisms of action for the treatment of many therapeutic antibodies, particularly cancer treatment and infectious diseases $[3,10]$. There are two types of Fc $\gamma$ Rs involved in the removal of pathogenic cells by leukocytes (Fig. 1B and 1C). Type I receptors include Fc $\gamma R I$ (CD64), Fc $\gamma R I I a / b / c ~(C D 32 a / b / c)$, and Fc $\gamma R I I I a / b$ (CD16a/b) belong to the immunoglobulin superfamily. Fc $\gamma$ RIIc (CD16c) expresses only about $15 \%$ of the total population; FcyRIIIb (CD16b) is expressed only in inactivated Polymorphonuclear (PMN) cells and has no signal transduction domain. Type II lectin receptors (CD23, CD209) have mainly immunomodulatory functions and are 
not directly involved in the killing of target cells $[16,17]$.

The immune complexes (ICs), composed of an antibodyopsonized pathogen activates several Fc $\gamma$ Rs to induce Antibody-Dependent Cellular Phagocytosis (ADCP) or Antibody-Dependent Cellular Cytotoxicity (ADCC) for eliminating pathogenic cells $[3,21,23]$ through intracellular signaling by the phosphorylation of immunoreceptor tyrosine-based activation motifs (ITAMs). Similarly, the ICs activate several FcyRs to remove pathogens using other mechanisms such as trogoptosis or the release of cytokines and chemokines [24,25]. In addition, ICs recruit the complement $\mathrm{Clq}$ proteins, which results in ICs activating the classical complement pathway (Fig. 1B). The activated complement proteins, $\mathrm{C} 5-\mathrm{C} 9$, form a membrane attack complex (MAC) on the target cell surface, which induce lysis the target cells, namely the Complement Dependent Cytotoxicity (CDC). Furthermore, the activated complement proteins, such as $\mathrm{C} 3 \mathrm{~b}$ or $\mathrm{C} 5$, would deposit on the target cell surface and the deposited complement proteins are capable of activating complement receptors (CRs) on effector cells and causing Complement-Dependent Cellular Phagocytosis (CDCP) or Cytotoxicity (CDCC) (Fig. 1B and C) [18].

Antibodies are further classified based on the heavy chain sequences. IgA has two subclasses (IgA1 and IgA2), which contain three alleles, respectively, and IgG has four subclasses (IgG1-4) (Fig. 1B). Although the four IgG subclasses have more than $90 \%$ identical amino acid sequences, each IgG subclass has a unique profile in terms of structural characteristics, sites of antigen binding, immune complex formation, complement activation, induction of

Table 2. Properties of human IgG subclasses

\begin{tabular}{|c|c|c|c|c|}
\hline & IgG1 & IgG2 & IgG3 & IgG4 \\
\hline $\begin{array}{l}\text { Amino acids in the } \\
\text { hinge region }\end{array}$ & 15 & 12 & $62^{\mathrm{a}}$ & 12 \\
\hline $\begin{array}{l}\text { Inter-heavy chain } \\
\text { disulfide bonds }\end{array}$ & 2 & 4 & $11^{\mathrm{a}}$ & 2 \\
\hline $\begin{array}{l}\text { Mean adult serum } \\
\text { level }(\mathrm{g} / \mathrm{L})\end{array}$ & 6.98 & 3.8 & 0.51 & 0.56 \\
\hline Half-life (days) & 21 & 21 & $7 \sim 21^{\mathrm{a}}$ & 21 \\
\hline Clq binding & ++ & + & +++ & - \\
\hline Fc $\gamma R I$ & +++ & - & ++++ & ++ \\
\hline $\mathrm{Fc}_{\mathrm{RIII}} \mathrm{H}_{131}$ & +++ & ++ & ++++ & ++ \\
\hline $\mathrm{F}_{\mathrm{c}} \gamma \mathrm{RIIa} \mathrm{R}_{\mathrm{R} 131}$ & +++ & + & ++++ & ++ \\
\hline Fc $\gamma$ RIIb/c & + & - & ++ & + \\
\hline $\mathrm{Fc}_{\mathrm{RIIIa}} 158$ & ++ & - & ++++ & - \\
\hline $\mathrm{Fc}_{\mathrm{R}} \mathrm{RIII}_{\mathrm{V} 158}$ & +++ & + & ++++ & ++ \\
\hline Fc $\gamma$ RIIIb & +++ & - & ++++ & - \\
\hline FcRn $($ at $\mathrm{pH}<6.5)$ & +++ & +++ & $++/+++^{\mathrm{a}}$ & +++ \\
\hline
\end{tabular}

${ }^{a}$ Depends on allotype.

Binding activities of IgG subclass to each Fc receptor are from Bruhns et al. and Lee et al. [20,127].
Fc $\gamma R$, half-life and placental transport (Table 2) [11,18,20, 26-28]. Functionally, IgG1 and IgG3 are potent inducers of Fc-mediated effector mechanisms such as ADCC, CDC, and ADCP $[3,16,17]$. Since the $\operatorname{IgG}_{\mathrm{H} 435 \mathrm{R}}$ binds to FcRn at both acidic and physiological $\mathrm{pH}$ conditions due to H435R, which is key residues for interacting with FcRn, the IgG3 has a limit in terms of serum half-life [29]. Nevertheless, some individuals with $\mathrm{G} 3 \mathrm{~m}$ allogeneic " $\mathrm{s}$ " or " 15 " markers (i.e., G3m (s) / G3m and G3m (st) / G3m allogenes) are found to have an extended $\operatorname{IgG} 3$ [28,29]. However, the extended serum half-life of IgG3-H435 does not improve the anti-cancer effect in a mouse model. Compared to the IgG3, the IgG2 has shown to be able to significantly induce superior complement and Fc-receptor-mediated responses to high-density epitopes such as polysaccharides but generally induces more subtle responses [28]. The hinge's stiffness of $\operatorname{IgG} 2$ may cause these unique biological characteristics, and the rigid hinge can provide improved agonistic activities of antibody IgG than that of the flexible hinge [30-32], which is proper for agonist antibody. As a representative example, Yu showed the importance of the hinge rigidity in the agonistic activity of antibodies with anti-CD40 antibodies [32].

Furthermore, antibodies have been shown to exhibit allelic mutations (antibody-allotypes), which can differ between individuals and ethnic groups. Currently, five human immunoglobulins heavy constant (IGHC) genes, IGHG1, IGHG2, IGHG3, IGHA2, and IGHE genes, are identified as antibody allotypes. Those are designated as Gm1, G2m, $\mathrm{G} 3 \mathrm{~m}, \mathrm{~A} 2 \mathrm{~m}$, and Em allotrope. Especially, the Gm polymorphism is determined by the IGHG1, IGHG2, and IGHG3 genes, which have alleles encoding allotypic antigenic determinants referred to as $\mathrm{G} 1 \mathrm{~m}, \mathrm{G} 2 \mathrm{~m}$, and $\mathrm{G} 3 \mathrm{~m}$ allotypes for markers of the human IgG1, IgG2, and IgG3 molecules (no $\mathrm{Gm}$ allotypes have been found on the IGHG4). At present, $18 \mathrm{Gm}$ allotypes are known: G1m [1,2,3,17], G2m [23], G3m [5,6,10,11,13-16,21,24,26-28] (Table 3). Moreover, specific $\mathrm{Gm}$ haplotypes are found in distinct biological human taxonomy. For example, $\mathrm{Gm} 5^{*} ; 3 ; .$. and $\mathrm{Gm} 5^{*} ; 3 ; 23$ are typically shown in Caucasoids, whereas three $\mathrm{Gm}$ haplotypes only occur in the Mongoloids: Gm $15,16^{*} ; 1,17 ;$,. largely in the northern hemisphere, and $\mathrm{Gm} 5^{*} ; 1,3 ; \ldots$ and Gm $5^{*} ; 1,3 ; 23$ in the southern hemisphere. Especially, the whole set of $\mathrm{Gm}$ haplotypes in the Negroids is unique, while the Caucasoids and mongoloids have two haplotypes in common, $\mathrm{Gm} 21^{*} ; 1,17 ; .$. and $\mathrm{Gm} 21^{*} ; 1,2,17 ; .$. [33].

Some antibody allotypes have been proven to be immunogenic, and this can induce the anti-allotype reaction during therapeutic monoclonal antibodies treatment. Therefore, it may crucial to consider the way to reduce their immunogenicity during therapeutic antibody development. Therapeutic antibodies are mostly based on the IgG1 isotype, so some 
Table 3. The isotypes, subclasses, and alleles of immunoglobulin heavy chain in humans

\begin{tabular}{|c|c|c|c|c|c|c|c|c|c|}
\hline \multirow{2}{*}{$\begin{array}{ccc}\text { Isotype } & \text { IgD } & \text { IgM } \\
\text { Subclass } & & \\
\text { Allotype } & & \end{array}$} & \multicolumn{2}{|c|}{$\overline{I g A}$} & \multicolumn{7}{|c|}{$\mathrm{IgG}$} \\
\hline & \multirow{2}{*}{\multicolumn{2}{|c|}{$\begin{array}{rr}\operatorname{IgA} 1 \quad \operatorname{IgA} 2 \\
\mathrm{~A} 2 \mathrm{~m} 1\end{array}$}} & \multicolumn{2}{|c|}{ IgG1 } & \multicolumn{2}{|l|}{$\mathrm{IgG} 2$} & \multicolumn{2}{|c|}{ IgG3 } & IgG4 \\
\hline & & & $\begin{array}{l}\text { G1m1 } \\
\text { [or G1m(a)] }\end{array}$ & $\begin{array}{l}\text { D12, L14 or } \\
\text { E12, M14 }\end{array}$ & $\begin{array}{l}\text { G2m23 } \\
\text { [or G2m (n)] }\end{array}$ & V45.1 & $\begin{array}{l}\text { G3m5 } \\
\text { [or G3m (b1)] }\end{array}$ & $\begin{array}{l}\text { R115, F116 or } \\
\text { H115, Y116 }\end{array}$ & \\
\hline & & $\mathrm{A} 2 \mathrm{~m} 2$ & $\begin{array}{l}\text { G1m2 } \\
\text { [or G1m(x)] }\end{array}$ & G110 & & & $\begin{array}{l}\text { G3m6 } \\
\text { [or G3m (c3)] }\end{array}$ & S44, E98 & \\
\hline & & & $\begin{array}{l}\text { G1m3 } \\
\text { [or G1m(f)] }\end{array}$ & R120 & & & $\begin{array}{l}\text { G3m10 } \\
\text { [or G3m (b5)] }\end{array}$ & S44, I101 & \\
\hline & & & $\begin{array}{l}\text { G1m17 } \\
\text { [or G1m(z)] }\end{array}$ & $\mathrm{K} 120$ & & & $\begin{array}{l}\text { G3m11 } \\
\text { [or G3m (b0)] }\end{array}$ & S44 or N44 & \\
\hline & & & G1m28 & R115, Y116 & & & $\begin{array}{l}\text { G3m13 } \\
\text { [or G3m (b3)] }\end{array}$ & S44, Q98 & \\
\hline & & & & & & & $\begin{array}{l}\text { G3m14 } \\
\text { [or G3m (b4)] }\end{array}$ & $\begin{array}{l}\text { M84, } \\
\text { R115,F116 }\end{array}$ & \\
\hline & & & & & & & $\begin{array}{l}\mathrm{G} 3 \mathrm{~m} 15 \\
\text { [or G3m (s)] }\end{array}$ & $\begin{array}{l}\text { M39, H115, } \\
\text { Y116 }\end{array}$ & \\
\hline & & & & & & & $\begin{array}{l}\text { G3m16 } \\
\text { [or G3m (t)] }\end{array}$ & W83 & \\
\hline & & & & & & & $\begin{array}{l}\text { G3m21 } \\
\text { [or G3m (g1)] }\end{array}$ & L82 or P82 & \\
\hline & & & & & & & $\begin{array}{l}\text { G3m24 } \\
\text { [or G3m (c5)] }\end{array}$ & S44, V101 & \\
\hline & & & & & & & $\begin{array}{l}\text { G3m26 } \\
\text { [or G3m (u)] }\end{array}$ & $\mathrm{R} 115$ & \\
\hline & & & & & & & $\begin{array}{l}\mathrm{G} 3 \mathrm{~m} 27 \\
\text { [or G3m (v)] }\end{array}$ & I101 & \\
\hline & & & & & & & $\begin{array}{l}\text { G3m28 } \\
\text { [or G3m (g5)] }\end{array}$ & R115, Y116 & \\
\hline
\end{tabular}

Antibody nomenclature is based on the IMGT database (http://imgt.org/) (IMGT numbering was used).

of them contain potential immunogenicity. Thus, the constant regions of the gammal chains are often engineered to replace the G1m3 allotype into less immunogenic G1m17 $(\mathrm{CH} 1 \mathrm{R} 120>\mathrm{K})(\mathrm{G} 1 \mathrm{~m} 17$ more extensively found in different populations) [33]. Recently, the anti-drug antibody response of adalimumab or infliximab was reported, but the correlations of allotype and anti-drug antibody responses are not clear until now [34]. So far, we are not fully aware of the immunological effects of these antibody allotypes because they have not yet been reviewed by modern technology. Antibody allotypes include the number of unknown variants, and how often they appear within and between groups. Antibody allotypes may have functional consequences affecting expression levels, half-life, effector functions by Fc $\gamma$ Rs or complement, Fc:Fc interaction and immunogenicity. It may have significant consequences for antibody-mediated immunotherapy. For instance, a recent study by Gestur Vidarsson research group demonstrated that the IgG3 allele has different ADCC activities while other IgG1, IgG2, and IgG4 allotypes did not show a significant difference [35]. Additionally, the IgG allele did not affect CDC activities [36].

\section{Antibody Discovery}

There are four primary techniques for antibody discovery technologies, which including i) mice immunization followed by hybridoma generation [5,37], ii) transgenic mice genetically engineered for producing human antibodies [38], iii) human B-cell repertoire technology [39,40], and iv) in vitro methods such as phage display, yeast display, ribosome display, bacterial display, mammalian cell surface display, and mRNA display [41-43].

Since Kohler and Milstein introduced the hybridoma method in 1975, the animal immunization became one of the most commonly used techniques for mAbs development, and various other techniques are often combined with the animal immunization. For example, mouse immunizations followed by hybridoma screening, bacterial display techniques, or single B-cell screening are widely used (Fig. 2) [39,4244]. Typically, a fusion of mouse B cells from the spleen with myeloma cells to generate hybridomas can be used for functional screening, such as ELISA assay [45,46]. However, even with automation, it is a slow process that does not comprehensively characterize the mouse antibody repertoire 


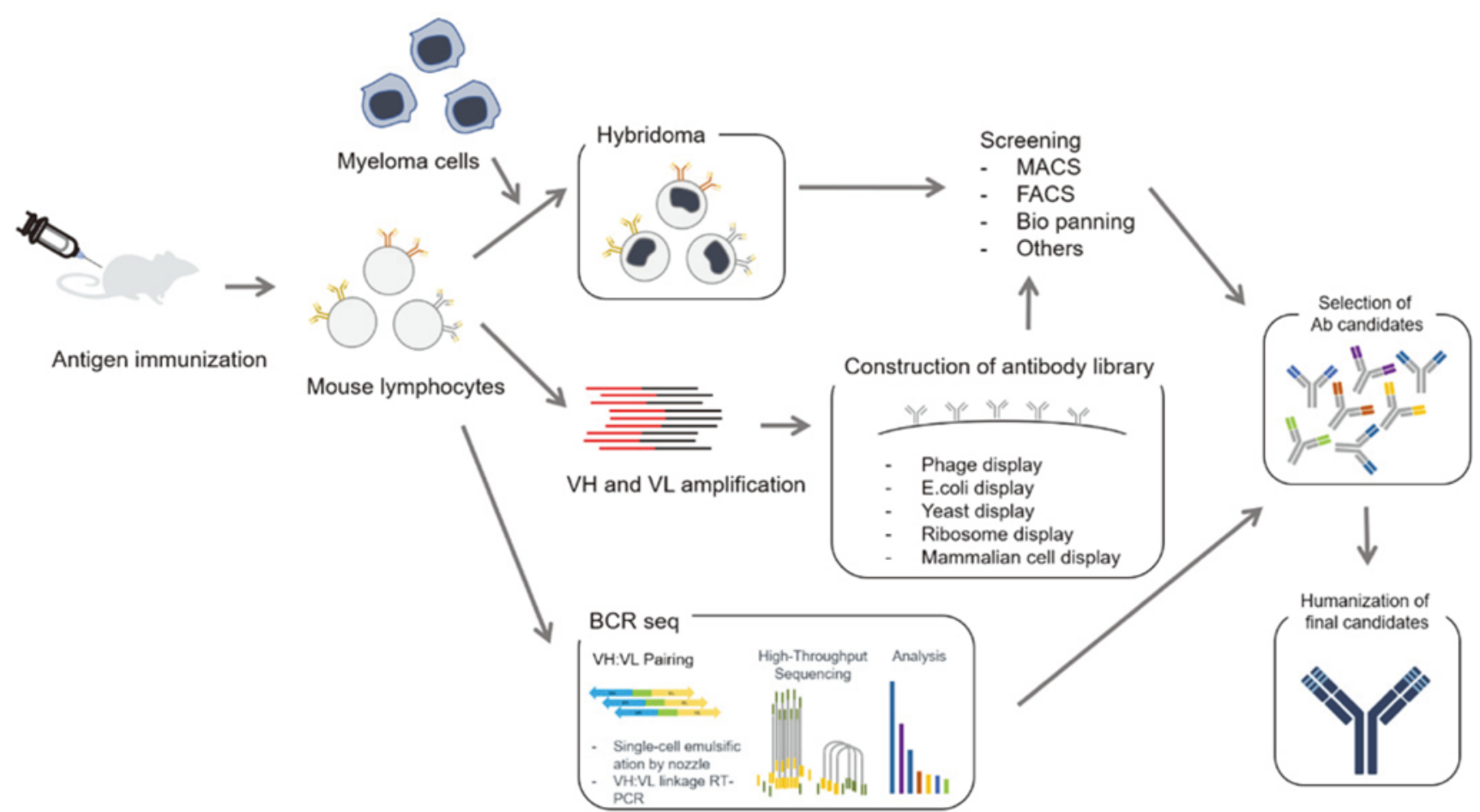

Fig. 2. Antibody discovery by animal immunization. The B cells harvested from spleen and blood, after immunization, can be immortalized by fusion with myeloma cell lines, as in traditional hybridoma techniques. The hybridomas can then be screened for specific antibodies by high throughput screening methods, biopanning, etc. The specific antibodies can be isolated by other methods, such as antibody libraries with display techniques. Finally, the specific antibodies can be discovered by the next-generation sequencing technology.

and can only analyze thousands of antibodies [45,47-49]. In bacterial display techniques, individual heavy and light chain genes and sequences, expressed on the bacterial surface, are obtained through polymerase chain reaction (PCR) of B cells in bulk and/or high-throughput sequencing of B cells in bulk. Then, the antibody libraries are screened with multiple rounds of fluorescence-activated cell sorting (FACS) for isolating antigen-specific binders. However, such methods have limitations that often result in antibodies with low selectivity and inferior biophysical properties compared to authentic human immunoglobulins due to the non-cognate pairing of heavy and light chain immunoglobulin (Ig). The single B-cell sequencing technologies with the natively paired $\mathrm{VH}: \mathrm{VL}$ antibody repertoire based on nextgeneration DNA sequencing (NGS) technology can overcome these limitations. To construct the cognate paired $\mathrm{VH}$ and VL gene, VH and VL ligation can be achieved by twosteps; i) single-cell emulsion lysis and ii) oligo-dT capture of VH and VL mRNA and reverse transcription (RT) and overlap-extension (OE) -PCR steps. The amplified VH and VL genes are displayed on the yeast surface as a Fab format, and then target-specific mAbs could be isolated by FACS [44]. However, mice may not be able to produce high affinity and/or non-specific antibodies against human proteins that are evolutionarily conserved compared to that of mice by $\mathrm{B}$ cell tolerance [50,51]. The reason is that human proteins are often recognized as self-antigens in mice, which can be solved by using animals that are evolutionarily distant from human beings. Various animals have been used for this purpose but were not routinely used to obtain mAbs, due to difficulties in establishing immortalized antibody-producing cell lines by hybridoma, viral transformation, or reprogramming [52-54]. In addition, a variety of state-of-the-art technologies are being developed. The most representative method is the high-throughput single-cell screening of IgG-secreting primary plasma B cells, which characterize the binding activities of antibodies against antigens $[55,56]$.

Contrarily, the human combinatorial antibody library based on phage, Escherichia coli (E. coli), ribosome, or yeast display can provide several advantages over animalbased methods, particularly because of the low cost, high flexibility, and time-efficiency. More importantly, there is no step for eliminating self-reactive B cells, and therefore high affinity and/or specific antibodies against human proteins can be discovered unlikely in animal immunization methods. Based on the antibody sequence source, the antibody libraries can be classified as immune, naïve, or synthetic antibody libraries. Immune antibody libraries include antibodies with superior affinity to the target 
relative to naïve or synthetic antibody libraries because the antibody genes and sequences are obtained from B cells of immunized animals. However, as mentioned above, there is a B cell tolerance issue $[50,52]$. The use of naïve antibody libraries is derived from germline sequences, genes rearranged from various naïve B cell sources, or synthetic antibody libraries that allow the selection of high-affinity antibodies against various antigens, including nonimmunogenic or self-antigens [57-59]. Various synthetic antibody libraries have been constructed and reported. Recently, the diversity of CDRs was introduced by codonbased mutagenesis at specific positions within CDR1, $\mathrm{CDR} 2$, and CDR3 sequences based on the BCR sequences of naïve human B-cells [60-62]. However, these antibody libraries generally use one or a few frameworks, thus losing the structural diversity of native antibodies that gives the CDRs a unique form that is thought to broaden the range of epitopes recognized for the target [60-62]. In addition, the isolated antibodies usually do not have high affinities against target molecules due to the lack of somatic hypermutations [60-62].

\section{Antibody Engineering}

The antibodies also can be engineered to obtain desired characteristics of selected leading candidates such as highaffinity against a target, low immunogenicity, improved effector function, improved protein production, improved stability, and others [63-66]. Depending on the antigen's location, antigens of monoclonal antibodies can be classified into two groups: membrane-bound antigen and soluble antigen [9]. FDA-approved monoclonal antibodies mainly target membrane-bound antigens, which include tumor surface markers (HER2, CD20, and CD19), tyrosine kinase receptors (EGFR and VEGFR), and cytokine receptors (IL6 receptor) [1,9]. As soluble antigens, there are the cytokines (TNFa, IL-6, IL-12, and IL-17), growth factors (VEGF) and other soluble disease mediators (IgE and C5) [1,9,64]. Moreover, bispecific antibody development has also been developed along with antibody engineering, and the current bispecific antibody aimed not only targeting two molecules but also engineered the $\mathrm{Fc}$ region of an antibody to induce enhanced or reduced effector function. After discovering therapeutic antibody candidates using the above methods, the next step is 'optimization of antibody efficacy.' Increasing the binding affinity against an antigen by 'affinity maturation' in vivo or in vitro has been the most common approach to improve the antibody efficacy $[67,68]$. However, in recent years, various methods have been used to improve the efficacy of antibodies [69-72].

\subsection{Affinity maturation}

Affinity maturation based on antibody CDR engineering can have various benefits: reduced doses, fewer side effects, and low-cost [73]. In general, therapeutic antibodies are expected to have a strong affinity of sub-nM for their antigen, and it is common to repeat the affinity maturation cycle once or multiple times to develop therapeutic antibodies [74]. There are three methods to enhance the affinity of antibodies: in vitro, in silico, and next-generation DNA sequencing (NGS) [67]. For in vitro affinity maturation, antibody libraries are constructed by random mutagenesis such as error-prone PCR and primers with degenerated codons, or targeted mutagenesis such as site-directed mutagenesis or alanine scanning [75,76]. Recent advances in antibody 3D structure prediction technology have led to the development of new methods for affinity maturation. One of the most important advantages of this in silico method is that all variants designed in the virtual library are enormous $\left(\sim 10^{40}\right)$ and can be retrieved in a short time [77]. In contrast, in vitro method only explores about $10^{10}$ candidates (limit of antibody surface display method), and the library screening process will take several weeks as well [78]. Finally, the NGS was combined with a protein display method (phage, E. coli, yeast, or ribosome system) to analyze a huge library produced by mutagenesis techniques. NGS technology, coupled with a protein display method, has made it possible to analyze vast numbers of single clones from antibody libraries generated by mutagenesis techniques. The conventional in vitro method analyzed about $10^{2}-10^{3}$ single clones using Sanger sequencing technology to select the final clone. However, the NGS technology provides much deeper insight into the diversity of libraries provided by more than $10^{7}$ sequences and provides us a deeper understanding of the immune system and engineering of antibody structures with antibody modeling technology [79].

\subsection{Soluble antigen targeting antibody}

In general, antibodies targeting cytokines aim to bind to the target cytokine and interfere with the interaction between the cytokine and the receptor. Since the antibody IgG has two Fab arms, it can inhibit two cytokines. In other words, the concentration of the antibody injected for therapeutic purposes should be at least half the concentration of the target cytokine present in the blood to inhibit the effect of the target cytokine completely. These characteristics of cytokine-blocking antibodies may have two potential limitations [80]. First, if the antigen concentration is too high, the required amount of antibody would be very high so that the therapeutic antibody will not be able to fulfill its role. Second, the antigen-binding antibody would circulate 


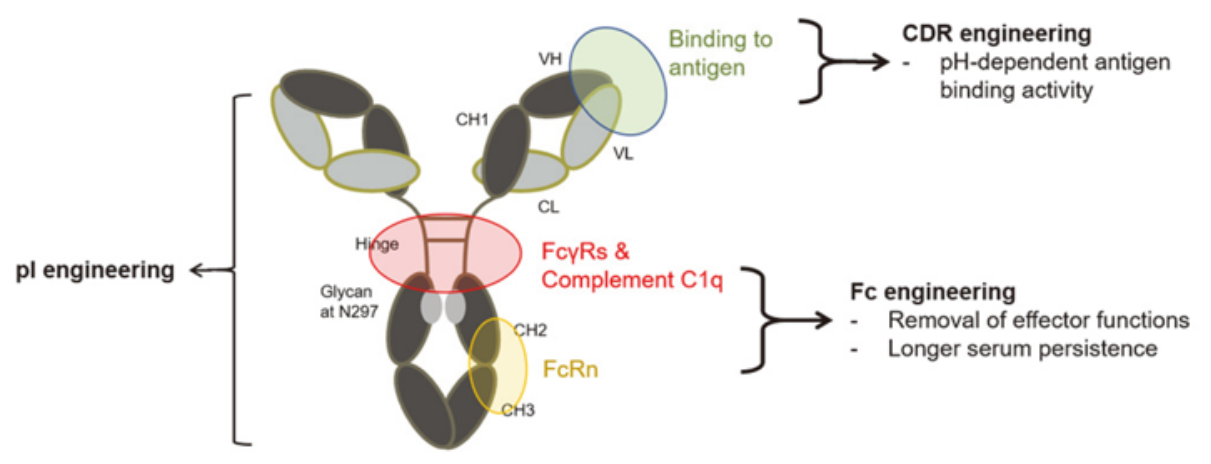

Fig. 3. Antibody engineering to develop a "sweeping antibody".

in the blood due to the FcRn-mediated antibody $\operatorname{IgG}$ recycling mechanism, resulting in an increase in antigen concentration in the blood. A newly developed antibody, "the sweeping antibody," which can solve these problems and works with the following mechanisms (Fig. 3) [70,8082]; 1) Binding to antigen in blood 2) Due to the isoelectronic point (pI) or the exposed positive charge clusters of the engineered sweeping antibody, it exists near the inner wall of the blood vessel, so it has a relatively high probability of pinocytosis. 3) After pinocytosis, a change in $\mathrm{pH}$ and ca concentration occurs in the endosome, resulting in separation of antigen and antibody. 4) Antigen without FcRn binding ability by endosomal sorting is the lysosomal pathway, and antibody with FcRn binding ability moves out of the cell through exocytosis. 5) The antibody moved out of the cell performs the role of step 1 again.

Unlike conventional blocking antibodies, the sweeping antibodies can 'sweep' target molecules from the blood continuously rather than once [80]. So, the sweeping antibody should have the following two properties; 1) binding to the antigen only in the blood and be separated from the antigen in the early endosome, 2) positive charge cluster or the positive net charge of the antibody to be located near the endothelium. To optimize the function of the sweeping antibody, two additional properties are required. The Better serum half-life of antibodies induces longer therapeutic antibody persistence in blood so that it will cause effective clearance of antigen by the sweeping antibody [70]. The significant role of the sweeping antibody is inhibiting the interaction between the antigen and its receptor and clearing the antigen in the blood. Thus, some Fc-mediated functions are not necessary, and other Fc-mediated function needs to be enhanced. For example, the enhanced serum half-life of sweeping antibody will induce enhanced therapeutic efficacy, but the sweeper antibodies do not need $\mathrm{Fc}$ receptor-mediated effector functions; therefore, the binding activities of the sweeper antibodies need to be removed [70]. Other engineered $\mathrm{Fc}$ variants that have decreased effector functions or enhanced serum half-life are listed in
Table 4. Of these, three $\mathrm{Fc}$ variants are notable. Two $\mathrm{Fc}$ variants, TM-YTE (L234F/L235E/P331S-M252Y/S254T/ T256E) and FQQ-YTE (L234F/L235Q/K322Q/M252Y/ S254T/T256E) have extended serum half-life and nondetectable ADCC and CDC activities and other Fc variant, $\operatorname{IgG} 2 \sigma$, does not bind to Fc $\gamma$ Rs and $\mathrm{C} 1 \mathrm{q}$ binding activities at all even in the form of immune complex mimic $[83,84]$.

\subsection{Cell surface antigen targeting antibody}

Receptor-targeting antibodies perform one of three roles; a receptor antagonist, a receptor agonist, or a linker between pathogenic and effector cells $[1,10,23,85]$. As mentioned earlier, antibody IgG has a wide variety of functions, but when acting as an antagonist, most of those functions are unnecessary because the consequence of $\mathrm{Fc} \gamma \mathrm{R}$ and complement-mediated effector functions is usually the death of target cell. Therefore, after FDA first approved nivolumab in 2014, many PD-1 blockade antibodies have been developed based on IgG4, which has a relatively weak effector function than IgG1 due to the above reasons [86-88]. However, IgG4 is still capable of recruiting several effector cells via Fc receptors, which can kill target cells and induce diverse immune responses such as ADCC, ADCP [89], CDC, CDCC, CDCP [18], trogocytosis [24], and NETosis [90,91]. Importantly, the recent research reports that PD-1 antibodies bound to T-cell in a tumor microenvironment induce trogocytosis by $\mathrm{Fc} \gamma \mathrm{R}$, which can remove antigen-antibody complex [92].

In contrast to antagonist antibodies, the agonistic antibodies need different functions comparing with the antagonistic antibody because the agonistic antibody is desired to activate the signaling of cell surface receptors. IgG has two $\mathrm{Fab}$ arms and $\operatorname{IgG} \mathrm{Fc}$ domain interacts with other IgG Fc domain so that the receptor bound IgGs can form clusters on the cell surface and induce the multimerization of receptors [93]. This multimerized receptor-bound IgG complexes can enhance the signaling transduction. The hexabody, which is developed by Genmab, is very suitable for this purpose $[71,94,95]$. The hexabody technology was developed 
Table 4. The list of the engineered Fc variants

\begin{tabular}{|c|c|c|}
\hline $\begin{array}{l}\text { Engineering and intended function } \\
\text { Remove effector functions }\end{array}$ & Mutation & Reference \\
\hline$\overline{\text { Aglycosylated }}$ & N297A or N297Q or N297G or T299L & $\overline{[18,128,129]}$ \\
\hline Reduced Fc $\gamma \mathrm{R}$ and $\mathrm{C} 1 \mathrm{q}$ binding & IgG1: L234A/L235A; IgG4:F234A/L235A & [130] \\
\hline & IgG2: H268Q/V309L/A330S/P331S & [131] \\
\hline & 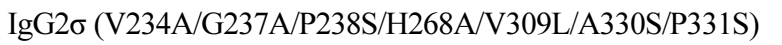 & [83] \\
\hline Reduced Fc $\gamma \mathrm{R}$ and $\mathrm{C} 1 \mathrm{q}$ binding and Enhanced & TM-YTE (L234F/L235E/P331S-M252Y/S254T/T256E) & [132] \\
\hline pH-dependent FcRn binding & FQQ-YTE (L234F/L235Q/K322Q/M252Y/S254T/T256E) & [132] \\
\hline \multicolumn{3}{|l|}{ Enhance ADCC } \\
\hline Increased Fc $\gamma$ RIIIa binding, Decreased Fc $\gamma$ RIIb binding & $\mathrm{S} 239 \mathrm{D} / \mathrm{I} 332 \mathrm{E} / \mathrm{A} 330 \mathrm{~L}$ & {$[104]$} \\
\hline \multirow[t]{4}{*}{ Increased Fc $\gamma$ RIIIa binding } & $\mathrm{S} 239 \mathrm{D} / \mathrm{I} 332 \mathrm{E}$ & {$[104]$} \\
\hline & F243L/R292P/Y300L/V305I/P396L & [133] \\
\hline & $\mathrm{S} 298 \mathrm{~A} / \mathrm{E} 333 \mathrm{~A} / \mathrm{K} 334 \mathrm{~A}$ & {$[134]$} \\
\hline & $\begin{array}{l}\text { A chain: } \mathrm{L} 234 \mathrm{Y} / \mathrm{L} 235 \mathrm{Q} / \mathrm{G} 236 \mathrm{~W} / \mathrm{S} 239 \mathrm{M} / \mathrm{H} 268 \mathrm{D} / \mathrm{D} 270 \mathrm{E} / \mathrm{S} 298 \mathrm{~A} \\
\text { B chain: } \mathrm{D} 270 \mathrm{E} / \mathrm{K} 326 \mathrm{D} / \mathrm{A} 330 \mathrm{M} / \mathrm{K} 334 \mathrm{E}\end{array}$ & {$[105]$} \\
\hline Added Fc $\alpha \mathrm{R}$ binding & IgG1/IgA “cross-isotype” antibody & {$[72]$} \\
\hline \multicolumn{3}{|l|}{ Enhance ADCP } \\
\hline Increased Fc $\gamma$ RIIa binding, Increased Fc $\gamma$ RIIIa binding & G236A/S239D/I332E & {$[107]$} \\
\hline Increased Fc $\gamma$ RIIa binding & S298G, T299A, N390D, E382V, M428L & [108] \\
\hline Added Fc $\alpha \mathrm{R}$ binding & IgG1/IgA “cross-isotype" antibody & {$[72]$} \\
\hline \multicolumn{3}{|l|}{ Enhance CDC } \\
\hline \multirow[t]{3}{*}{ Increased $\mathrm{C} 1 \mathrm{q}$ binding } & K326W/E333S & {$[135]$} \\
\hline & $\mathrm{S} 267 \mathrm{E} / \mathrm{H} 268 \mathrm{~F} / \mathrm{S} 324 \mathrm{~T}$ & [109] \\
\hline & IgG1/IgG3 cross subclass & [136] \\
\hline Increased \& selective $\mathrm{C} 1 \mathrm{q}$ binding & T299L/K320E/Q386R & [18] \\
\hline $\begin{array}{l}\text { Increased } \mathrm{Clq} \text { binding via hexamerization } \\
\text { Increase serum half-life }\end{array}$ & $\mathrm{E} 345 \mathrm{R} / \mathrm{E} 430 \mathrm{G} / \mathrm{S} 440 \mathrm{Y}$ or $\mathrm{E} 345 \mathrm{R}$ & [71] \\
\hline \multirow[t]{4}{*}{ Enhanced $\mathrm{pH}$-dependent FcRn binding } & $\mathrm{M} 252 \mathrm{Y} / \mathrm{S} 254 \mathrm{~T} / \mathrm{T} 256 \mathrm{E}$ & [114] \\
\hline & $\mathrm{H} 433 \mathrm{~K} / \mathrm{N} 434 \mathrm{~F}$ & {$[115]$} \\
\hline & M428L/N434S & [111] \\
\hline & L309D/Q311H/N434S & {$[20]$} \\
\hline \multicolumn{3}{|l|}{ Decrease serum half-life } \\
\hline Enhanced FcRn binding activity at both $\mathrm{pH}$ & M252Y/S254T/T256E/H433K/N434F & [118] \\
\hline \multicolumn{3}{|l|}{ Selective Fc receptor binding } \\
\hline Fc $\gamma$ RI-binding & E382V/M428I & {$[137]$} \\
\hline Fc $\gamma$ RIIIa-binding & S239T, P248L, V264E, V282M, T299A, L309Q, A378V & [21] \\
\hline Increased \& selective $\mathrm{C} 1 \mathrm{q}$ binding & T299L/K320E/Q386R & [18] \\
\hline
\end{tabular}

based on an engineered Fc domain to improve Fc:Fc interaction. For instance, IgG-E345R forms hexamer only on the cell surface, but IgG-RGY (E345R/E430G/S440Y) has a much stronger Fc:Fc interaction than that of $\mathrm{IgG}-$ E345R and forms hexamer in solution [71,94]. Therefore, OX40, 4-1BB, CD37, DR4, and DR5 could be suitable target receptors because one hexabody theoretically binds to twelve target receptors on the cell surface and forms the signaling cluster, thereby maximizing signal transmission by the target receptor [95]. Currently, HexaBody®-DR5/ DR5 and DuoHexaBody®-CD37 (GEN3009) are under clinical trial [96]. Anti-CD40 antibodies took a different strategy instead of hexabody technology to multiply CD40 on the cell surface [30,97]. CD40-bound antibodies recruit leukocytes expressing Fc receptors through the $\operatorname{IgG} \mathrm{Fc}$ domain and the multimerized Fc receptor could induce the oligomerization of CD40. For this Fc receptor-mediated oligomerization, Fc $\gamma \mathrm{RIIb}$ is supposed to be the most crucial receptor $[98,99]$, and thus the CD40 antibody had been developed in the form of $\operatorname{IgG} 2$, which has similar Fc $\gamma$ RIIb but weaker other FcyR binding activities comparing to IgG1 [30].

Finally, the therapeutic antibody can play a role as a linker between the pathogenic cell, and the effector cell. The Fab domain of antibody IgG is generally bound to a pathogenic cell-specific marker, and the antibody IgG Fc domain recruits effector cells through the Fc receptor [17]. Activated effector cells by several Fc receptors can activate 


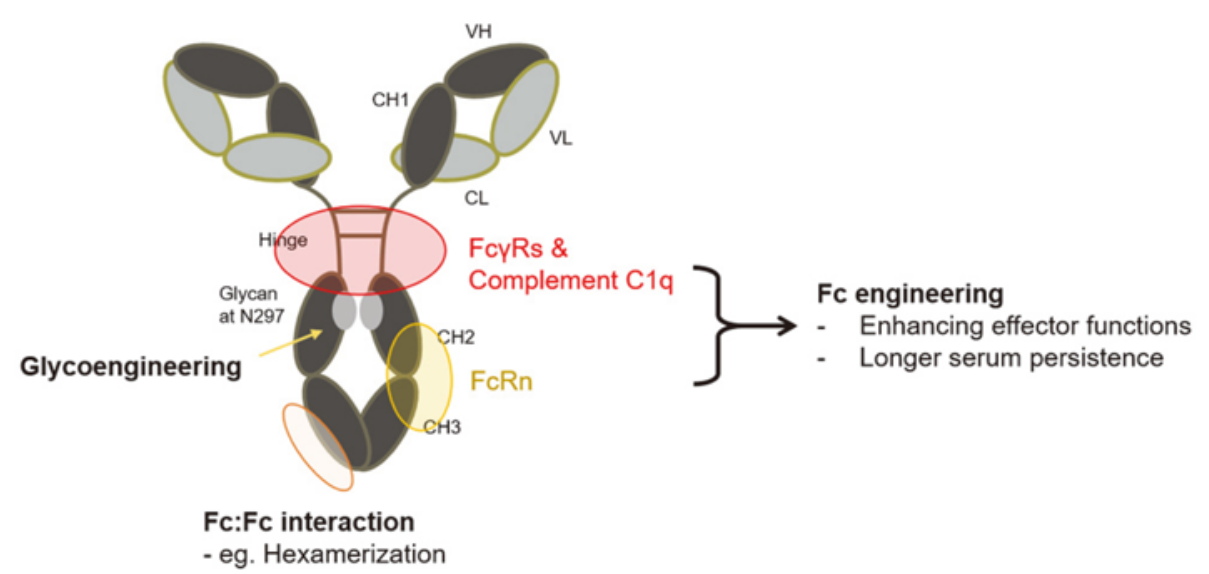

Fig. 4. Possible Fc engineering to modulate Fc-mediated functions.

effector functions [18,21,24,25] and the improved effector functions can be achieved by increasing affinity for Fc $\gamma \mathrm{R}$ through site-specific mutation of the $\mathrm{Fc}$ domain or glycoengineering of a single sugar chain ( $\mathrm{N}$-glycan) attached to N297 of the Fc domain [3,5,99]. For glycoengineering, afucosylated antibody is the most successful example. The absence of core fucose on $\mathrm{Fc} \mathrm{N}$-glycans has been shown to increase ADCC activity by 40-80 fold increase in IgG1 Fc binding affinity for FcyRIIIa present on immune effector cells such as natural killer cells (NK cells) [100] and afucosylated IgG approved by FDA in Japan in 2012 and USA in 2018 [69,102]. On the other hand, a high level of terminal sialylation is associated with reduced inflammation [69].

For site-specific mutation of the $\mathrm{Fc}$ domain, there are several ways to modulate the Fc-mediated effector function, including point mutations, bacterial or yeast display, and asymmetric $\mathrm{Fc}$ engineering (Fig. 4). Each $\mathrm{Fc}$ variants modifying $\mathrm{Fc}-\mathrm{Fc} \gamma \mathrm{R}$ interaction and the effector functions are listed in Table 4. Generally, Fc engineering has been focused on increasing Fc $\gamma$ RIIIa binding activity of the Fc domain because FcyRIIIa is the most potent $\mathrm{Fc}$ receptor for mediating $\mathrm{ADCC}$ and $\mathrm{NK}$ cells, the most important contributor to ADCC, express only FcyRIIIa [102,103]. Briefly, according to the research conducted by Lazar, they engineered a series of Fc variants with optimized Fc $\gamma \mathrm{R}$ affinity and reported that S239D/I332E and S239D/I332E/ A330L as two $\mathrm{Fc}$ variants with enhanced ADCC activity [104]. In addition, Mimoto designed Fc variants with an asymmetrically engineered $\mathrm{Fc}$ domain by introducing different amino acid substitutions in each Fc polypeptide chain (A chain: L234Y/L235Q/G236W/S239M/H268D/ D270E/S298A and B chain: D270E/K326D/A330M/K334E) which has more than 1000 -fold enhanced affinity to the Fc $_{\text {RIIIa }} 158$ and more than a 2000 -fold enhanced affinity to the FcyRIIIa $a_{F 158}$ with enhanced ADCC activity [105].
Moreover, Fc $\gamma$ RIIa is a potential target receptor for enhancing ADCP because FcyRIIa is known as a key receptor for ADCP and has a higher expression level than that of Fc $\gamma$ RIIIa in the macrophages [106]. The Fc engineering for enhancing ADCP had been focused on increasing the FcrRIIa-binding activity of the Fc domain [107,108]. However, a recent study showed that the contribution of Fc $\gamma$ RIIIa in ADCP might be equivalent to that of Fc $\gamma$ RIIa [21]. There were other efforts to enhance Fc-mediated effector functions by increasing complement binding activity and complement-mediated effector functions are key effector functions of anti-CD20 therapeutic antibodies such as Rituximab and Ofatumumab $[12,18]$. Moore developed the EFT-Fc variant (S267E/H268F/S324T) with 47-fold enhanced C1q binding activity and 6.9-fold CDC activity comparing with that of wild type IgG1 [109]. On the other hand, Lee developed the A801-Fc variant (T299L/K320E/ Q386R) that increases C1q binding activity but does not bind to all human and murine Fc $\gamma$ Rs at all [18]. Additionally, the hexabody has greatly enhanced $\mathrm{C} 1 \mathrm{q}$ binding activities and CDC activity over IgG1 due to avidity [71]. However, since the hexamerized IgG can induce unwanted complement activation in the blood, the researchers had studied to find the appropriate $\mathrm{Fc}: \mathrm{Fc}$ interaction strength to form a hexamer only on the cell surface and found that IgGE345R forms hexabody only on the cell surface unlikely IgG-RGY [71,110].

\subsection{Engineering pharmacokinetics}

There are several reasons why antibody $\operatorname{IgG}$ is most commonly used as a therapeutic protein, but one of the reasons is that antibody IgG has a much longer half-life ( 21 days) in blood compared to that of other serum proteins due to the FcRn-mediated recycling of antibody IgG. The enhanced serum half-life of an antibody can provide several advantages, which include less frequent administration and 
reduced doses, which can bring improved patient compliance and lower costs. In some cases, better PK enhances the therapeutic efficacy of anti-cancer antibodies [111]. Briefly, $\mathrm{IgG}$ is recycled by the following steps; 1) antibodies and other serum proteins are internalized by vascular endothelial cell pinocytosis, 2) acidification of endosome and interaction of FcRn and IgG (highly localized FcRn in early endosome), 3) endosomal sorting of FcRn-bound IgG vs. FcRn-unbound proteins, 4) exocytosis of FcRn-bound IgG but lysosomal degradation of FcRn-unbound proteins, and 5) re-endocytosis of un-released $\mathrm{IgG}$ that failed to release from FcRn during exocytosis [112]. Therefore, for efficient FcRn-medium IgG recycling, the ability to bind to FcRn strongly at endosomal $\mathrm{pH}$ (about 6) and dissociate from FcRn quickly at physiological $\mathrm{pH}$ are important $[20,113]$. There were diverse efforts to develop the engineered $\mathrm{Fc}$ variant, which has enhanced serum half-life and were a few successful $\mathrm{Fc}$ variants, such as YTE-Fc, LS-Fc, KF-Fc, and DHS-Fc $[20,111,114,115]$. These four $\mathrm{Fc}$ variants showed 4-6 folds extended $\beta$-phase serum half-life in human FcRn transgenic mice comparing with that of wild type $\operatorname{IgG}[20,111,114,115]$. For LS-Fc, ravulizumab, a complement C5-inhibiting antibody with a serum half-life of $\sim 50$ days, was FDAapproved for paroxysmal nocturnal hemoglobinuria, and VRC-HIVMAB080-00-AB (VRC01LS), with broad HIV1 neutralizing activity, is under clinical phase $\mathrm{Ib} / 2 \mathrm{a}$ [116]. For YTE-Fc, MEDI8897, a respiratory syncytial virus (RSV)-neutralizing antibody was shown to have a serum half-life of $\sim 70$ days in infants in a phase $1 b / 2$ a study [117]. On the other hand, the FcRn binding ability of the Fc domain can be engineered in different ways. For example, 'Abdeg' has substantial FcRn-binding activities to FcRn at both acidic and physiological $\mathrm{pH}$, so it is capable of inducing fast clearance of endogenous IgG by blocking FcRn-mediated recycling of endogenous IgG for clearing pathogenic IgG (e.g., Autoantibodies) in severe autoimmune diseases [118,119].

\section{Bispecific Antibodies}

Since Nisonoff and his colleagues first demonstrated two different antigen-binding sites containing bispecific antibody (bsAb) in 1961, the development of bsAb has been evolved along with antibody engineering and biology. Currently, two bsAbs are commercially available (emicizumab and blinatumomab), and over 100 bsAbs are in clinical development [120]. As the term describes its name, bsAbs are designated to recognize two different epitopes or antigens. Notably, numerous formats provide different characteristics toward targets. Generally, natural antibodies hold two antigen-binding sites that are identical and comprise determinants from VH and VL domains. So, the different strategies are demonstrated to develop different formats of bsAbs, including asymmetric, symmetric, and fragmentbased formats. The different formats of bsAbs can affect manufacturing, valency, Fc-mediated effector functions, and in vivo half-life [121].

Asymmetric formats are achieved by forcing proper heavy and light chain pairing and/or heavy chain heterodimerization during the co-expression process for the four polypeptide chains. However, the HL chain mispairing may occur during production, so the alternative approaches that promote heavy chain heterodimerization by mutation, such as sperate expression of both specificities as halfmolecules; parent antibodies through post-production assembly or recombinant half-molecules [121]. With these strategies, one or two specific binding sites $(1+1$ or $1+2)$ can be constructed (Fig. 5). Symmetric formats are designed by fusing antibody fragments to native antibody molecules through co-expression of one to two polypeptides chains. So, most of the symmetric formats composed of two specific binding sites $(2+2)$ designs. However, the additional antibody fragments may bring improper properties, such as loss of stability and reduced solubility, because these additional antibody fragments differ the size and antibody architecture. Thus, this can be causative of the impairment in physicochemical and/or pharmacokinetic. Therefore, the optimization of linker length and domain position is required for the optimal engagement of symmetric bsAbs. In contrast to the asymmetric and the symmetric formats, fragmentbased formats can be established by a simple combination of multiple antibody fragments, which can construct into $1+1,1+2$, and $2+2$ fragment-based structure. Since they do not contain the $\mathrm{Fc}$ region, this allows high yield and reduced costs during production. However, the absence of the Fc region may cause a reduced half-life and lack of effector functions.

These distinct formats of bsAbs from three strategies obtain various obligate mechanisms based on sequential binding of the two binding domains, including in-trans binding, in-cis binding for inhibition or activation, co-factor mimetic, and piggybacking [121]. The in-trans binding concepts of obligate bsAbs induce exclusive activation of the effector cells in the presence of target cells. For example, MGD014, currently on phase I trial, is intended to redirect and/or to activate $\mathrm{T}$ cell by targeting CD3 molecules and the HIV-1 envelope [122]. On the other hand, an in-cis binding mechanism aims to crosslink the specific cell surface receptors, which can induce either inhibition or activation. As representative bsAbs, BFKB8488A is currently on clinical trial phase II, and PRV-3279 has completed phase I. These bsAbs target two molecules on the specific cell surface. For instance, the PRV-3279 is diabody format 

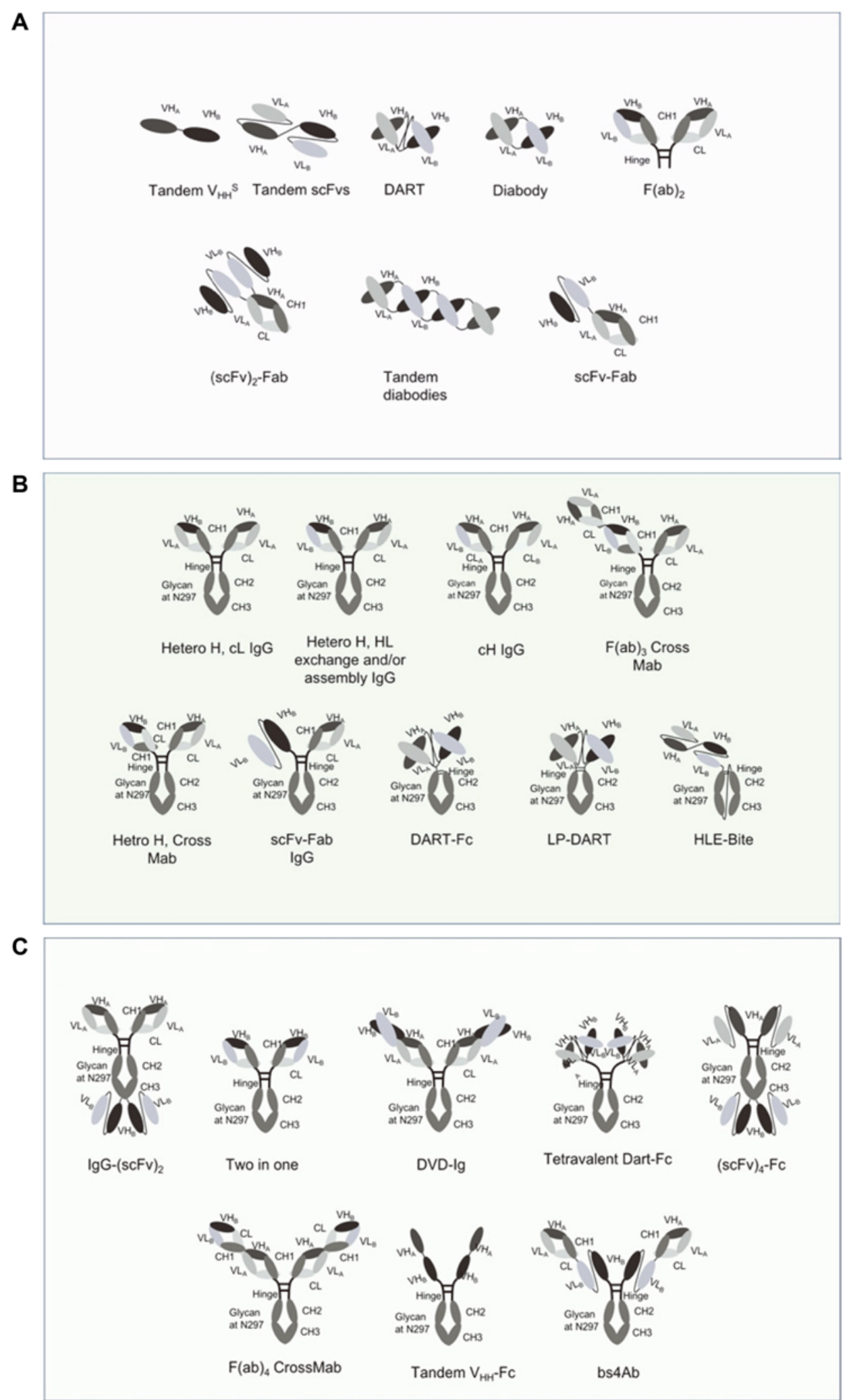

Fig. 5. Three different formats of bsAbs. (A) The fragment-based formats of bsAbs, these formats can be constructed by a simple combination of multiple antibody fragments. (B) Asymmetric formats of bsAbs, these specific formats can be achieved by VH and VL pairing or heavy chain heterodimerization during the co-expression process for the four polypeptide chains. (C) Symmetric formats of bsAbs, these formats can be designed by fusing antibody fragments to native antibody molecules through co-expression of one to two polypeptides chains. 
bsAbs that target the CD32b and CD79b on the surface of B lymphocyte and inhibit effector function from mediating immune-mediated disorders [123]. Also, the blinatumomab is one of the approved bsAbs which contain fragmentbased tandem scFv $1+1$ format. This specific bsAb can target CD19 and CD3, which allow cytotoxic $\mathrm{T}$ cell function toward malignant B cells [124]. Furthermore, bsAbs can be functioned as co-factor mimetic, which can produce precise enzyme and substrate positioning. For instance, one of commercially available bsAbs, emicizumab, is the asymmetric $1+1$ hetero $\mathrm{H}$ cL IgG4 with hingestabilization and $\mathrm{pI}$-engineered format and designated to alternate a critical clotting factor in the treatment of hemophilia. The structure of this bsAb imitates the cofactor FVIII function, and this allows the binding to FIXa enzyme and FX zymogen, which can mediate proper positioning and induce FIXa-catalysed FX activation [125]. Lastly, the bsAb under piggybacking mechanisms provide the translocation of binding arms to inaccessible cellular compartments. For instance, the Vobarilizumab is the fragment-based bsAb, which contains tandem $\mathrm{V}_{\mathrm{HH}}$ [antiIL6 and anti-human serum albumin (HAS)]. This significant structure and design allow the bsAb to penetrate into tissue and inhibit the IL- 6 mediated inflammatory parameters while anti-HAS binding site allows prolonging half extensions [126].

\section{Conclusion}

IgG has several binding molecules, including antigen, six Fc $\gamma$ Rs, complement C1q, FcRn, FcRL5, TRIM21, etc. However, we still do not understand the precise role in antibody functions. To improve therapeutic efficacy, we need a deeper and accurate understanding of the antibody and its functions. An efficacious strategy in the development of therapeutic antibodies will be obtained when using antibodies with each function of the antibody adjusted to the characteristics of each disease based on an accurate understanding of the various functions of IgG. Furthermore, applications of bispecific antibodies analogies also can be a future-oriented approach. Currently, two bsAbs are available in markets, and 100 of them are in clinical trials, bsAbs design and development also become a fascinating opportunity for novel antibodies as well as antibody engineering.

\section{Acknowledgement}

This work was supported by Creative-Pioneering Researchers Program through Seoul National University (SNU).

\section{Ethical Statements}

The authors declare no conflict of interest.

Neither ethical approval nor informed consent was required for this study.

\section{References}

1. Scott, A. M., J. D. Wolchok, and L. J. Old (2012) Antibody therapy of cancer. Nat. Rev. Cancer. 12: 278-287.

2. Weiner, L. M., R. Surana, and S. Wang (2010) Monoclonal antibodies: Versatile platforms for cancer immunotherapy. Nat. Rev. Immunol. 10: 317-327.

3. Biburger, M., A. Lux, and F. Nimmerjahn (2014) How immunoglobulin $\mathrm{G}$ antibodies kill target cells: Revisiting an old paradigm. Adv. Immunol. 124: 67-94.

4. Starr, C. G. and P. M. Tessier (2019) Selecting and engineering monoclonal antibodies with drug-like specificity. Curr. Opin. Biotechnol. 60: 119-127.

5. Strohl, W. R. (2018) Current progress in innovative engineered antibodies. Protein Cell. 9: 86-120.

6. Kretschmer, A., R. Schwanbeck, T. Valerius, and T. Rösner (2017) Antibody isotypes for tumor immunotherapy. Transfus Med. Hemother. 44: 320-326.

7. Yang, Y. (2015) Cancer immunotherapy: Harnessing the immune system to battle cancer. J. Clin. Invest. 125: 3335-3337.

8. DiLillo, D. J. and J. V. Ravetch (2015) Differential Fc-receptor engagement drives an anti-tumor vaccinal effect. Cell. 161: 1035-1045.

9. Weiner, G. J. (2015) Building better monoclonal antibody-based therapeutics. Nat. Rev. Cancer. 15: 361-370.

10. Reichert, J. M. (2014) Antibody Fc: Linking adaptive and innate immunity. MAbs. 6: 619-621.

11. Lu, L. L., T. J. Suscovich, S. M. Fortune, and G. Alter (2018) Beyond binding: Antibody effector functions in infectious diseases. Nat. Rev. Immunol. 18: 46-61.

12. Teeling, J. L., R. R. French, M. S. Cragg, J. van den Brakel, M. Pluyter, H. Huang, C. Chan, P. W. H. I. Parren, C. E. Hack, M. Dechant, T. Valerius, J. G. J. van de Winkel, and M. J. Glennie (2004) Characterization of new human CD20 monoclonal antibodies with potent cytolytic activity against non-Hodgkin lymphomas. Blood. 104: 1793-1800.

13. Goulet, D. R. and W. M. Atkins (2020) Considerations for the design of antibody-based therapeutics. J. Pharm. Sci. 109: 74-103.

14. Wang, W., S. Singh, D. L. Zeng, K. King, and S. Nema (2007) Antibody structure, instability, and formulation. J. Pharm. Sci. 96: 1-26.

15. Murphy, K. and C. Weaver (2016) Janeway's Immunobiology. 9th ed. W.W. Norton \& Company, NY, USA.

16. Bruhns, P. and F. Jönsson (2015) Mouse and human FcR effector functions. Immunol. Rev. 268: 25-51.

17. Pincetic, A., S. Bournazos, D. J. DiLillo, J. Maamary, T. T. Wang, R. Dahan, B. M. Fiebiger, and J. V. Ravetch (2014) Type $\mathrm{i}$ and type II $\mathrm{Fc}$ receptors regulate innate and adaptive immunity. Nat. Immunol. 15: 707-716.

18. Lee, C. H., G. Romain, W. Yan, M. Watanabe, W. Charab, B. Todorova, J. Lee, K. Triplett, M. Donkor, O. I. Lungu, A. Lux, N. Marshall, M. A. Lindorfer, O. R. L. Goff, B. Balbino, T. H. Kang, H. Tanno, G. Delidakis, C. Alford, R. P. Taylor, F. Nimmerjahn, N. Varadarajan, P. Bruhns, Y. J. Zhang, and G. Georgiou (2017) IgG Fc domains that bind C1q but not effector $\mathrm{Fc} \gamma$ receptors delineate the importance of complement- 
mediated effector functions. Nat. Immunol. 18: 889-898.

19. Lee, C. H., D. K. Choi, H. J. Choi, M. Y. Song, and Y. S. Kim (2010) Expression of soluble and functional human neonatal Fc receptor in Pichia pastoris. Protein Expr. Purif. 71: 42-48.

20. Lee, C. H., T. H. Kang, O. Godon, M. Watanabe, G. Delidakis, C. M. Gillis, D. Sterlin, D. Hardy, M. Cogné, L. E. Macdonald, A. J. Murphy, N. Tu, J. Lee, J. R. McDaniel, E. Makowski, P. M. Tessier, A. S. Meyer, P. Bruhns, and G. Georgiou (2019) An engineered human $\mathrm{Fc}$ domain that behaves like a $\mathrm{pH}$-toggle switch for ultra-long circulation persistence. Nat. Commun. 10: 5031.

21. Kang, T. H., C. H. Lee, G. Delidakis, J. Jung, O. Richard-Le Goff, J. Lee, J. E. Kim, W. Charab, P. Bruhns, and G. Georgiou (2019) An engineered human Fc variant with exquisite selectivity for FcyRIIIa 158 reveals that ligation of FcyRIIIa mediates potent antibody dependent cellular phagocytosis with GM-CSF-differentiated macrophages. Front. Immunol. 10: 562.

22. Kim, S. M., K. H. Chang, and D. J. Oh (2018) Effect of environmental parameters on glycosylation of recombinant immunoglobulin $\mathrm{G}$ produced from recombinant $\mathrm{CHO}$ cells. Biotechnol. Bioprocess Eng. 23: 456-464.

23. Golay, J. and M. Introna (2012) Mechanism of action of therapeutic monoclonal antibodies: Promises and pitfalls of in vitro and in vivo assays. Arch. Biochem. Biophys. 526: 146-153.

24. Matlung, H. L., L. Babes, X. W. Zhao, M. van Houdt, L. W. Treffers, D. J. van Rees, K. Franke, K. Schornagel, P. Verkuijlen, H. Janssen, P. Halonen, C. Lieftink, R. L. Beijersbergen, J. H. W. Leusen, J. J. Boelens, I. Kuhnle, J. van der Werff Ten Bosch, K. Seeger, S. Rutella, D. Pagliara, T. Matozaki, E. Suzuki, C. W. Menke-van der Houven van Oordt, R. van Bruggen, D. Roos, R. A. W. van Lier, T. W. Kuijpers, P. Kubes, and T. K. van den Berg (2018) Neutrophils kill antibody-opsonized cancer cells by trogoptosis. Cell Rep. 23: 3946-3959.

25. Yeap, W. H., K. L. Wong, N. Shimasaki, E. C. Y. Teo, J. K. S. Quek, H. X. Yong, C. P. Diong, A. Bertoletti, Y. C. Linn, and S. C. Wong (2016) CD16 is indispensable for antibody-dependent cellular cytotoxicity by human monocytes. Sci. Rep. 6: 34310 .

26. Lux, A., X. Yu, C. N. Scanlan, and F. Nimmerjahn (2013) Impact of immune complex size and glycosylation on IgG binding to human Fc $\gamma$ Rs. J. Immunol. 190: 4315-4323.

27. Teeling, J. L., W. J. M. Mackus, L. J. J. M. Wiegman, J. H. N. van den Brakel, S. A. Beers, R. R. French, T. van Meerten, S. Ebeling, T. Vink, J. W. Slootstra, P. W. H. I. Parren, M. J. Glennie, and J. G. J. van de Winkel (2006) The biological activity of human CD20 monoclonal antibodies is linked to unique epitopes on CD20. J. Immunol. 177: 362-371.

28. Vidarsson, G., G. Dekkers, and T. Rispens (2014) IgG subclasses and allotypes: From structure to effector functions. Front. Immunol. 5: 520

29. Stapleton, N. M., J. T. Andersen, A. M. Stemerding, S. P. Bjarnarson, R. C. Verheul, J. Gerritsen, Y. Zhao, M. Kleijer, I. Sandlie, M. de Haas, I. Jonsdottir, C. Ellen van der Schoot, and G. Vidarsson (2011) Competition for FcRn-mediated transport gives rise to short half-life of human IgG3 and offers therapeutic potential. Nat. Commun. 2: 599.

30. Khalil, M. and R. H. Vonderheide (2007) Anti-CD40 agonist antibodies: Preclinical and clinical experience. Update Cancer Ther. 2: 61-65.

31. Yu, X., H. T. C. Chan, C. M. Orr, O. Dadas, S. G. Booth, L. N. Dahal, C. A. Penfold, L. O'Brien, C. I. Mockridge, R. R. French, P. Duriez, L. R. Douglas, A. R. Pearson, M. S. Cragg, I. Tews, M. J. Glennie, and A. L. White (2018) Complex interplay between epitope specificity and isotype dictates the biological activity of anti-human CD40 antibodies. Cancer Cell. 33: 664-675.

32. Yu, X., H. T. C. Chan, H. Fisher, C A. Penfold, J. Kim, T. Inzhelevskaya, C. I. Mockridge, R. R. French, P. J. Duriez, L. R. Douglas, V. English, J. S. Verbeek, A. L. White, I. Tews, M. J.
Glennie, and M. S. Cragg (2020) Isotype switching converts anti-CD40 antagonism to agonism to elicit potent antitumor activity. Cancer Cell. 37: 850-866.

33. Lefranc, M. P. and G. Lefranc (2012) Human Gm, Km, and Am allotypes and their molecular characterization: A remarkable demonstration of polymorphism. Methods Mol. Biol. 882: 635-680.

34. Murdaca, G., S. Negrini, M. Greco, C. Schiavi, F. Giusti, M. Borro, and F. Puppo (2019) Immunogenicity of infliximab and adalimumab. Expert. Opin. Drug Saf. 18: 343-345.

35. de Taeye, S. W., A. E. H. Bentlage, M. M. Mebius, J. I. Meesters, S. Lissenberg-Thunnissen, D. Falck, T. Sénard, N. Salehi, M. Wuhrer, J. Schuurman, A. F. Labrijn, T. Rispens, and G. Vidarsson (2020) Fc $\gamma$ R binding and ADCC activity of human IgG allotypes. Front. Immunol. 11: 740.

36. Redpath, S., T. Michaelsen, I. Sandlie, and M. R. Clark (1998) Activation of complement by human IgG1 and human IgG3 antibodies against the human leucocyte antigen CD52. Immunology. 93: 595-600.

37. Nelson, A. L., E. Dhimolea, and J. M. Reichert (2010) Development trends for human monoclonal antibody therapeutics. Nat. Rev. Drug Discov. 9: 767-774.

38. Jakobovits, A., R. G. Amado, X. Yang, L. Roskos, and G. Schwab (2007) From XenoMouse technology to panitumumab, the first fully human antibody product from transgenic mice. Nat. Biotechnol. 25: 1134-1143.

39. Georgiou, G., G. C. Ippolito, J. Beausang, C. E. Busse, H. Wardemann, and S. R. Quake (2014) The promise and challenge of high-throughput sequencing of the antibody repertoire. Nat. Biotechnol. 32: 158-168.

40. Lee, J. (2019) Molecular-level antibody repertoire profiling and engineering: Implications for developing next-generation diagnostics, therapeutics, and vaccines. Biotechnol. Bioprocess Eng. 24: 8-11.

41. Frenzel, A., T. Schirrmann, and M. Hust (2016) Phage displayderived human antibodies in clinical development and therapy. MAbs. 8: 1177-1194.

42. Harvey, B. R., G. Georgiou, A. Hayhurst, K. J. Jeong, B. L. Iverson, and G. K. Rogers (2004) Anchored periplasmic expression, a versatile technology for the isolation of highaffinity antibodies from Escherichia coli-expressed libraries. Proc. Natl. Acad. Sci. USA. 101: 9193-9198.

43. Boder, E. T. and K. D. Wittrup (1997) Yeast surface display for screening combinatorial polypeptide libraries. Nat. Biotechnol. 15: 553-557.

44. Wang, B., B. J. DeKosky, M. R. Timm, J. Lee, E. Normandin, J. Misasi, R. Kong, J. R. McDaniel, G. Delidakis, K. E. Leigh, T. Niezold, C. W. Choi, E. G. Viox, A. Fahad, A. Cagigi, A. Ploquin, K. Leung, E. S. Yang, W. P. Kong, W. N. Voss, A. G. Schmidt, M. A. Moody, D. R. Ambrozak, A. R. Henry, F. Laboune, J. E. Ledgerwood, B. S. Graham, M. Connors, D. C. Douek, N. J. Sullivan, A. D. Ellington, J. R. Mascola, and G. Georgiou (2018) Functional interrogation and mining of natively paired human $\mathrm{V}_{\mathrm{H}}: \mathrm{V}_{\mathrm{L}}$ antibody repertoires. Nat. Biotechnol. 36: 152-155.

45. Love, J. C., J. L. Ronan, G. M. Grotenbreg, A. G. van der Veen, and H. L. Ploegh (2006) A microengraving method for rapid selection of single cells producing antigen-specific antibodies. Nat. Biotechnol. 24: 703-707.

46. Han, G. R. and M. G. Kim (2019) Design, synthesis, and evaluation of gold nanoparticle-antibody-horseradish peroxidase conjugates for highly sensitive chemiluminescence immunoassay (hs-CLIA). Biotechnol. Bioprocess Eng. 24: 206-214.

47. Coronella, J. A., P. Telleman, T. D. Truong, F. Ylera, and R. P. Junghans (2000) Amplification of IgG VH and VL (Fab) from single human plasma cells and B cells. Nucleic Acids Res. 28: e85.

48. Tiller, T., E. Meffre, S. Yurasov, M. Tsuiji, M. C. Nussenzweig, and H. Wardemann (2008) Efficient generation of monoclonal 
antibodies from single human B cells by single cell RT-PCR and expression vector cloning. J. Immunol. Methods. 329: 112-124.

49. Crosnier, C., N. Staudt, and G. J. Wright (2010) A rapid and scalable method for selecting recombinant mouse monoclonal antibodies. BMC Biol. 8: 76.

50. Wardemann, H. and M. C. Nussenzweig (2007) B-cell selftolerance in humans. Adv. Immunol. 95: 83-110.

51. Wardemann, H., S. Yurasov, A. Schaefer, J. W. Young, E. Meffre, and M. C. Nussenzweig (2003) Predominant autoantibody production by early human B cell precursors. Science. 301: 1374-1377.

52. Köhler, G and C. Milstein (1975) Continuous cultures of fused cells secreting antibody of predefined specificity. Nature. 256: 495-497.

53. Traggiai, E., S. Becker, K. Subbarao, L. Kolesnikova, Y. Uematsu, M. R. Gismondo, B. R. Murphy, R. Rappuoli, and A. Lanzavecchia (2004) An efficient method to make human monoclonal antibodies from memory B cells: Potent neutralization of SARS coronavirus. Nat. Med. 10: 871-875.

54. Kwakkenbos, M. J., S. A. Diehl, E. Yasuda, A. Q. Bakker, C. M. M. van Geelen, M. V. Lukens, G. M. van Bleek, M. N. Widjojoatmodjo, W. M. J. M. Bogers, H. Mei, A. Radbruch, F. A. Scheeren, H. Spits, and T. Beaumont (2010) Generation of stable monoclonal antibody-producing B cell receptor-positive human memory B cells by genetic programming. Nat. Med. 16: 123-128.

55. Eyer, K., R. C. L. Doineau, C. E. Castrillon, L. Briseño-Roa, V. Menrath, G. Mottet, P. England, A. Godina, E. Brient-Litzler, C. Nizak, A. Jensen, A. D. Griffiths, J. Bibette, P. Bruhns, and J. Baudry (2017) Single-cell deep phenotyping of IgG-secreting cells for high-resolution immune monitoring. Nat. Biotechnol. 35: 977-982.

56. Gérard, A., A. Woolfe, G. Mottet, M. Reichen, C. Castrillon, V. Menrath, S. Ellouze, A. Poitou, R. Doineau, L. Briseno-Roa, P. Canales-Herrerias, P. Mary, G. Rose, C. Ortega, M. Delincé, S. Essono, B. Jia, B. Iannascoli, O. Richard-Le Goff, R. Kumar, S. N. Stewart, Y. Pousse, B. Shen, K. Grosselin, B. Saudemont, A. Sautel-Caillé, A. Godina, S. McNamara, K. Eyer, G. A. Millot, J. Baudry, P. England, C. Nizak, A. Jensen, A. D. Griffiths, P. Bruhns, and C. Brenan (2020) High-throughput single-cell activity-based screening and sequencing of antibodies using droplet microfluidics. Nat. Biotechnol. 38: 715-721.

57. Sheets, M. D., P. Amersdorfer, R. Finnern, P. Sargent, E. Lindqvist, R. Schier, G. Hemingsen, C. Wong, J. C. Gerhart, and J. D. Marks (1998) Efficient construction of a large nonimmune phage antibody library: The production of high-affinity human single-chain antibodies to protein antigens. Proc. Natl. Acad. Sci. USA. 95: 6157-6162.

58. Vaughan, T. J., A. J. Williams, K. Pritchard, J. K. Osbourn, A. R. Pope, J. C. Earnshaw, J. McCafferty, R. A. Hodits, J. Wilton, and K. S. Johnson (1996) Human antibodies with sub-nanomolar affinities isolated from a large non-immunized phage display library. Nat. Biotechnol. 14: 309-314.

59. Hoogenboom, H. R. (2005) Selecting and screening recombinant antibody libraries. Nat. Biotechnol. 23: 1105-1116.

60. Rothe, C., S. Urlinger, C. Löhning, J. Prassler, Y. Stark, U. Jäger, B. Hubner, M. Bardroff, I. Pradel, M. Boss, R. Bittlingmaier, T. Bataa, C. Frisch, B. Brocks, A. Honegger, and M. Urban (2008) The human combinatorial antibody library HuCAL GOLD combines diversification of all six CDRs according to the natural immune system with a novel display method for efficient selection of high-affinity antibodies. J. Mol. Biol. 376: 1182-1200.

61. Prassler, J., S. Thiel, C. Pracht, A. Polzer, S. Peters, M. Bauer, S. Nörenberg, Y. Stark, J. Kölln, A. Popp, S. Urlinger, and M. Enzelberger (2011) HuCAL PLATINUM, a synthetic fab library optimized for sequence diversity and superior performance in mammalian expression systems. J. Mol. Biol. 413: 261-278.

62. Baek, D. S. and Y. S. Kim (2014) Construction of a large synthetic human fab antibody library on yeast cell surface by optimized yeast mating. J. Microbiol. Biotechnol. 24: 408-420.

63. Haraya, K., T. Tachibana, and T. Igawa (2019) Improvement of pharmacokinetic properties of therapeutic antibodies by antibody engineering. Drug Metab. Pharmacokinet. 34: 25-41.

64. Schmid, A. S. and D. Neri (2019) Advances in antibody engineering for rheumatic diseases. Nat. Rev. Rheumatol. 15: 197-207.

65. Chiu, M. L. and G. L. Gilliland (2016) Engineering antibody therapeutics. Curr. Opin. Struct. Biol. 38: 163-173.

66. Carvalho, R. J. (2019) Comparison of cationic flocculants for the clarification of $\mathrm{CHO}$-derived monoclonal antibodies. Biotechnol. Bioprocess Eng. 24: 754-760.

67. Tabasinezhad, M., Y. Talebkhan, W. Wenzel, H. Rahimi, E. Omidinia, and F. Mahboudi (2019) Trends in therapeutic antibody affinity maturation: From in-vitro towards nextgeneration sequencing approaches. Immunol. Lett. 212: 106-113.

68. Kim, J. Y., H. W. Yoo, P. G. Lee, S. G. Lee, J. H. Seo, and B. G. Kim (2019) In vivo protein evolution, next generation protein engineering strategy: from random approach to target-specific approach. Biotechnol. Bioprocess Eng. 24: 85-94.

69. Yu, X., M. J. E. Marshall, M. S. Cragg, and M. Crispin (2017) Improving antibody-based cancer therapeutics through glycan engineering. BioDrugs. 31: 151-166.

70. Sampei, Z., K. Haraya, T. Tachibana, T. Fukuzawa, M. ShidaKawazoe, S. W. Gan, Y. Shimizu, Y. Ruike, S. Feng, T. Kuramochi, M. Muraoka, T. Kitazawa, Y. Kawabe, T. Igawa, K. Hattori, and J. Nezu (2018) Antibody engineering to generate SKY59, a longacting anti-C5 recycling antibody. PLoS One. 13: e0209509.

71. Diebolder, C. A., F. J. Beurskens, R. N. de Jong, R. I. Koning, K. Strumane, M. A. Lindorfer, M. Voorhorst, D. Ugurlar, S. Rosati, A. J. R. Heck, J. G. J. van de Winkel, I. A. Wilson, A. J. Koster, R. P. Taylor, E. O. Saphire, D. R. Burton, J. Schuurman, P. Gros, and P. W. H. I. Parren (2014) Complement is activated by IgG hexamers assembled at the cell surface. Science. 343: 1260-1263.

72. Kelton, W., N. Mehta, W. Charab, J. Lee, C. Lee, T. Kojima, T. H. Kang, and G. Georgiou (2014) IgGA: A "cross-isotype" engineered human Fc antibody domain that displays both IgGlike and IgA-like effector functions. Chem. Biol. 21: 1603-1609.

73. Igawa, T., H. Tsunoda, T. Kuramochi, Z. Sampei, S. Ishii, and K. Hattori (2011) Engineering the variable region of therapeutic IgG antibodies. MAbs. 3: 243-252.

74. Steinwand, M., P. Droste, A. Frenzel, M. Hust, S. Dübel, and T. Schirrmann (2014) The influence of antibody fragment format on phage display based affinity maturation of IgG. MAbs. 6: 204-218.

75. Lou, J. and J. D. Marks (2010) Affinity maturation by chain shuffling and site directed mutagenesis. pp. 377-396. In: R. Kontermann and S. Dübel (eds.). Antibody Engineering. Springer, Berlin, Heidelberg, Germany.

76. Fujii, I. (2004) Antibody affinity maturation by random mutagenesis. pp. 345-359. In: B. K. C. Lo (ed.). Antibody Engineering: Methods and Protocols. Humana Press, Totowa, NJ, USA.

77. Mahajan, S. P., B. Meksiriporn, D. Waraho-Zhmayev, K. B. Weyant, I. Kocer, D. C. Butler, A. Messer, F. A. Escobedo, and M. P. DeLisa (2018) Computational affinity maturation of camelid single-domain intrabodies against the nonamyloid component of alpha-synuclein. Sci. Rep. 8: 17611.

78. Nelson, A. L. and J. M. Reichert (2009) Development trends for therapeutic antibody fragments. Nat Biotechnol. 27: 331-337.

79. Rouet, R., K. J. L. Jackson, D. B. Langley, and D. Christ (2018) Next-generation sequencing of antibody display repertoires. Front. Immunol. 9: 118.

80. Igawa, T., K. Haraya, and K. Hattori (2016) Sweeping antibody as a novel therapeutic antibody modality capable of eliminating soluble antigens from circulation. Immunol. Rev. 270: 132-151.

81. Igawa, T., S. Ishii, T. Tachibana, A. Maeda, Y. Higuchi, S. Shimaoka, C. Moriyama, T. Watanabe, R. Takubo, Y. Doi, T. 
Wakabayashi, A. Hayasaka, S. Kadono, T. Miyazaki, K. Haraya, Y. Sekimori, T. Kojima, Y. Nabuchi, Y. Aso, Y. Kawabe, and K. Hattori (2010) Antibody recycling by engineered pH-dependent antigen binding improves the duration of antigen neutralization. Nat. Biotechnol. 28: 1203-1207.

82. Igawa, T., A. Maeda, K. Haraya, T. Tachibana, Y. Iwayanagi, F. Mimoto, Y. Higuchi, S. Ishii, S. Tamba, N. Hironiwa, K. Nagano, T. Wakabayashi, H. Tsunoda, and K. Hattori (2013) Engineered monoclonal antibody with novel antigen-sweeping activity in vivo. PLoS One. 8: e63236.

83. Vafa, O., G. L. Gilliland, R. J. Brezski, B. Strake, T. Wilkinson, E. R. Lacy, B. Scallon, A. Teplyakov, T. J. Malia, and W. R. Strohl (2014) An engineered $\mathrm{Fc}$ variant of an $\mathrm{IgG}$ eliminates all immune effector functions via structural perturbations. Methods. 65: 114-126.

84. Derebe, M. G., R. K. Nanjunda, G. L. Gilliland, E. R. Lacy, and M. L. Chiu (2018) Human IgG subclass cross-species reactivity to mouse and cynomolgus monkey $\mathrm{Fc} \gamma$ receptors. Immunol. Lett. 197: 1-8.

85. Braig, F., A. Brandt, M. Goebeler, H. P. Tony, A. K. Kurze, P. Nollau, T. Bumm, S. Böttcher, R. C. Bargou, and M. Binder (2017) Resistance to anti-CD19/CD3 BiTE in acute lymphoblastic leukemia may be mediated by disrupted CD19 membrane trafficking. Blood. 129: 100-104.

86. Chen, X., X. Song, K. Li, and T. Zhang (2019) FC $\gamma$ R-binding is an important functional attribute for immune checkpoint antibodies in cancer immunotheraphy. Front. Immunol. 10: 292.

87. Zhang, T., X. Song, L. Xu, J. Ma, Y. Zhang, W. Gong, Y. Zhang, X. Zhou, Z. Wang, Y. Wang, Y. Shi, H. Bai, N. Liu, X. Yang, X. Cui, Y. Cao, Q. Liu, J. Song, Y. Li, Z. Tang, M. Guo, L. Wang, and K. Li (2018) The binding of an anti-PD-1 antibody to Fc $\gamma$ RI has a profound impact on its biological functions. Cancer Immunol. Immunother. 67: 1079-1090.

88. Liu, J., G. Wang, L. Liu, R. Wu, Y. Wu, C. Fang, X. Zhou, J. Jiao, Y. Gu, H. Zhou, Z. Xie, Z. Sun, D. Chen, K. Dai, D. Wang, W. Tang, and T. T. C. Yang (2019) Study of the interactions of a novel monoclonal antibody, $\mathrm{mAb} 059 \mathrm{c}$, with the hPD-1 receptor. Sci. Rep. 9: 17830.

89. Boross, P. and J. H. W. Leusen (2012) Mechanisms of action of CD20 antibodies. Am. J. Cancer Res. 2: 676-690.

90. Guglietta, S., A. Chiavelli, E. Zagato, C. Krieg, S. Gandini, P. S. Ravenda, B. Bazolli, B. Lu, G. Penna, and M. Rescigno (2016) Coagulation induced by C3aR-dependent NETosis drives protumorigenic neutrophils during small intestinal tumorigenesis. Nat. Commun. 7: 11037.

91. Chen, K., H. Nishi, R. Travers, N. Tsuboi, K. Martinod, D. D. Wagner, R. Stan, K. Croce, and T. N. Mayadas (2012) Endocytosis of soluble immune complexes leads to their clearance by Fc $\gamma$ RIIIB but induces neutrophil extracellular traps via Fc $\gamma$ RIIA in vivo. Blood. 120: 4421-4431.

92. Arlauckas, S. P., C. S. Garris, R. H. Kohler, M. Kitaoka, M. F. Cuccarese, K. S. Yang, M. A. Miller, J. C. Carlson, G. J. Freeman, R. M. Anthony, R. Weissleder, and M. J. Pittet (2017) In vivo imaging reveals a tumor-associated macrophage-mediated resistance pathway in anti-PD-1 therapy. Sci. Transl. Med. 9: eaal3604.

93. Preiner, J., N. Kodera, J. Tang, A. Ebner, M. Brameshuber, D. Blaas, N. Gelbmann, H. J. Gruber, T. Ando, and P. Hinterdorfer (2014) IgGs are made for walking on bacterial and viral surfaces. Nat. Commun. 5: 4394.

94. de Jong, R. N., F. J. Beurskens, S. Verploegen, K. Strumane, M. D. van Kampen, M. Voorhorst, W. Horstman, P. J. Engelberts, S. C. Oostindie, G. Wang, A. J. R. Heck, J. Schuurman, and P. W. H. I. Parren (2016) A novel platform for the potentiation of therapeutic antibodies based on antigen-dependent formation of IgG hexamers at the cell surface. PLoS Biol. 14: e1002344.

95. Zhang, D., A. A. Armstrong, S. H. Tam, S. G. McCarthy, J. Luo, G. L. Gilliland, and M. L. Chiu (2017) Functional optimization of agonistic antibodies to OX40 receptor with novel Fc mutations to promote antibody multimerization. MAbs. 9: 1129-1142.

96. Genmab, Global Pipeline. https://www.genmab.com/pipeline.

97. Dahan, R., B. C. Barnhart, F. Li, A. P. Yamniuk, A. J. Korman, and J. V. Ravetch (2016) Therapeutic activity of agonistic, human anti-CD40 monoclonal antibodies requires selective Fc $\gamma R$ engagement. Cancer Cell. 29: 820-831.

98. White, A. L., H. T. C. Chan, A. Roghanian, R. R. French, C. I. Mockridge, A. L. Tutt, S. V. Dixon, D. Ajona, J. S. Verbeek, A. Al-Shamkhani, M. S. Cragg, S. A. Beers, and M. J. Glennie (2011) Interaction with Fc $\gamma$ RIIB Is critical for the agonistic activity of anti-CD40 monoclonal antibody. J. Immunol. 187: 1754-1763.

99. Mastrangeli, R., W. Palinsky, and H. Bierau (2019) Glycoengineered antibodies: towards the next-generation of immunotherapeutics. Glycobiology. 29: 199-210.

100. Gerdes, C. A., V. G. Nicolini, S. Herter, E. van Puijenbroek, S. Lang, M. Roemmele, E. Moessner, O. Freytag, T. Friess, C. H. Ries, B. Bossenmaier, H. J. Mueller, and P. Umaña (2013) GA201 (RG7160): A novel, humanized, glycoengineered anti-EGFR antibody with enhanced ADCC and superior in vivo efficacy compared with cetuximab. Clin. Cancer Res. 19: 1126-1138.

102. Yamane-Ohnuki, N., S. Kinoshita, M. Inoue-Urakubo, M. Kusunoki, S. Iida, R. Nakano, M. Wakitani, R. Niwa, M. Sakurada, K. Uchida, K. Shitara, and M. Satoh (2004) Establishment of FUT8 knockout Chinese hamster ovary cells: An ideal host cell line for producing completely defucosylated antibodies with enhanced antibody-dependent cellular cytotoxicity. Biotechnol. Bioeng. 87: 614-622.

102. Hatjiharissi, E., L. Xu, D. D. Santos, Z. R. Hunter, B. T. Ciccarelli, S. Verselis, M. Modica, Y. Cao, R. J. Manning, X. Leleu, E. A. Dimmock, A. Kortsaris, C. Mitsiades, K. C. Anderson, E. A. Fox, and S. P. Treon (2007) Increased natural killer cell expression of CD16, augmented binding and ADCC activity to rituximab among individuals expressing the Fc \{gamma\}RIIIa$158 \mathrm{~V} / \mathrm{V}$ and V/F polymorphism. Blood. 110: 2561-2564.

103. Nimmerjahn, F. and J. V. Ravetch (2008) Fc $\gamma$ receptors as regulators of immune responses. Nat. Rev. Immunol. 8: 34-47.

104. Lazar, G. A., W. Dang, S. Karki, O. Vafa, J. S. Peng, L. Hyun, C. Chan, H. S. Chung, A. Eivazi, S. C. Yoder, J. Vielmetter, D. F. Carmichael, R. J. Hayes, and B. I. Dahiyat (2006) Engineered antibody $\mathrm{Fc}$ variants with enhanced effector function. Proc. Natl. Acad. Sci. USA. 103: 4005-4010.

105. Mimoto, F., T. Igawa, T. Kuramochi, H. Katada, S. Kadono, T. Kamikawa, M. Shida-Kawazoe, and K. Hattori (2013) Novel asymmetrically engineered antibody Fc variant with superior FcyR binding affinity and specificity compared with afucosylated Fc variant. MAbs. 5: 229-236.

106. Dahal, L. N., L. Dou, K. Hussain, R. Liu, A. Earley, K. L. Cox, S. Murinello, I. Tracy, F. Forconi, A. J. Steele, P. J. Duriez, D. Gomez-Nicola, J. L. Teeling, M. J. Glennie, M. S. Cragg, and S. A. Beers (2017) STING activation reverses lymphoma-mediated resistance to antibody immunotherapy. Cancer Res. 77: 3619-3631.

107. Richards, J. O., S. Karki, G. A. Lazar, H. Chen, W. Dang, and J. R. Desjarlais (2008) Optimization of antibody binding to Fc $\gamma$ RIIa enhances macrophage phagocytosis of tumor cells. Mol. Cancer Ther. 7: 2517-2527.

108. Jung, S. T., W. Kelton, T. H. Kang, D. T. W. Ng, J. T. Andersen, I. Sandlie, C. A. Sarkar, and G. Georgiou (2013) Effective phagocytosis of low Her2 tumor cell lines with engineered, aglycosylated igg displaying high Fc $\gamma$ RIIa affinity and selectivity. ACS Chem. Biol. 8: 368-375.

109. Moore, G. L., H. Chen, S. Karki, and G. A. Lazar (2010) Engineered Fc variant antibodies with enhanced ability to recruit complement and mediate effector functions. MAbs. 2: 181-189.

110. Cook, E. M., M. A. Lindorfer, H. van der Horst, S. Oostindie, F. J. Beurskens, J. Schuurman, C. S. Zent, R. Burack, P. W. H. I. 
Parren, and R. P. Taylor (2016) Antibodies that efficiently form hexamers upon antigen binding can induce complementdependent cytotoxicity under complement-limiting conditions. J. Immunol. 197: 1762-1775.

111. Zalevsky, J., A. K. Chamberlain, H. M. Horton, S. Karki, I. W. L. Leung, T. J. Sproule, G. A. Lazar, D. C. Roopenian, and J. R. Desjarlais (2010) Enhanced antibody half-life improves in vivo activity. Nat. Biotechnol. 28: 157-159.

112. Stapleton, N. M., H. K. Einarsdóttir, A. M. Stemerding, and G. Vidarsson (2015) The multiple facets of FcRn in immunity. Immunol. Rev. 268: 253-268.

113. Lencer, W. I. and R. S. Blumberg (2005) A passionate kiss, then run: Exocytosis and recycling of IgG by FcRn. Trends Cell Biol. 15: 5-9.

114. Ghetie, V., S. Popov, J. Borvak, C. Radu, D. Matesoi, C. Medesan, R. J. Ober, and E. S. Ward (1997) Increasing the serum persistence of an IgG fragment by random mutagenesis. Nat. Biotechnol. 15: 637-640.

115. Vaccaro, C., R. Bawdon, S. Wanjie, R. J. Ober, and E. S. Ward (2006) Divergent activities of an engineered antibody in murine and human systems have implications for therapeutic antibodies. Proc. Natl. Acad. Sci. USA. 103: 18709-18714.

116. U.S. National Library of Medicine, Study Record Detail, Dual bNAb Treatment in Children. https://clinicaltrials.gov/ct2/show/ NCT03707977.

117. Domachowske, J. B., A. A. Khan, M. T. Esser, K. Jensen, T. Takas, T. Villafana, F. Dubovsky, and M. P. Griffin (2018) Safety, tolerability and pharmacokinetics of MEDI8897, an extended half-life single-dose respiratory syncytial virus prefusion Ftargeting monoclonal antibody administered as a single dose to healthy preterm infants. Pediatr. Infect. Dis. J. 37: 886-892.

118. Vaccaro, C., J. Zhou, R. J. Ober, and E. S. Ward (2005) Engineering the $\mathrm{Fc}$ region of immunoglobulin $\mathrm{G}$ to modulate in vivo antibody levels. Nat. Biotechnol. 23: 1283-1288.

119. Ulrichts, P., A. Guglietta, T. Dreier, T. van Bragt, V. Hanssens, E. Hofman, B. Vankerckhoven, P. Verheesen, N. Ongenae, V. Lykhopiy, F. J. Enriquez, J. Cho, R. J. Ober, E. S. Ward, H. de Haard, and N. Leupin (2018) Neonatal Fc receptor antagonist efgartigimod safely and sustainably reduces IgGs in humans. $J$. Clin. Invest. 128: 4372-4386.

120. U.S. National Library of Medicine, Bispecific mAbs Studies List Results. https:/clinicaltrials.gov/ct2/results?cond=bispecific $\&$ recrs $=\mathrm{b} \&$ recrs $=\mathrm{a} \&$ recrs $=\mathrm{f} \&$ recrs $=\mathrm{d} \&$ recrs $=$ e\&age $\mathrm{v}=\&$ gndr $=\&$ type $=\& \mathrm{rslt}=\&$ Search $=$ Apply.

121. Labrijn, A. F., M. L. Janmaat, J. M. Reichert, and P. W. H. I. Parren (2019) Bispecific antibodies: a mechanistic review of the pipeline. Nat. Rev. Drug Discov. 18: 585-608.

122. U.S. National Library of Medicine, Study Record Detail, MGD014 in HIV-Infected Individuals on Suppressive Antiretroviral Therapy. https://clinicaltrials.gov/ct2/show/NCT03570918?cond $=$ MGD014\&draw $=2 \&$ rank $=1$.

123. U.S. National Library of Medicine, Study Record Detail, A Study to Evaluate the Safety, Pharmacokinetics, Pharmacodynamics, and Immunogenicity of PRV-3279 in Healthy Subjects (PREVAIL1). https://clinicaltrials.gov/ct2/show/NCT03955666 ?cond $=$ PRV-3279\&draw $=2 \&$ rank $=1$.

124. Burt, R., D. Warcel, and A. K. Fielding (2019) Blinatumomab, a bispecific B-cell and T-cell engaging antibody, in the treatment of B-cell malignancies. Hum Vaccines Immunother. 15: 594-602.

125. Franchini, M., G. Marano, I. Pati, F. Candura, S. Profili, E. Veropalumbo, F. Masiello, L. Catalano, V. Piccinini, S. Vaglio,
S. Pupella, and G. M. Liumbruno (2019) Emicizumab for the treatment of haemophilia A: A narrative review. Blood Transfus. 17: 223-228.

126. Van Roy, M., C. Ververken, E. Beirnaert, S. Hoefman, J. Kolkman, M. Vierboom, E. Breedveld, B. 't Hart, S. Poelmans, L. Bontinck, A. Hemeryck, S. Jacobs, J. Baumeister, and H. Ulrichts (2015) The preclinical pharmacology of the high affinity anti-IL-6R Nanobody ${ }^{\circledR}$ ALX-0061 supports its clinical development in rheumatoid arthritis. Arthritis Res. Ther. 17: 135.

127. Bruhns, P., B. Iannascoli, P. England, D. A. Mancardi, N. Fernandez, S. Jorieux, and M. Daëron (2009) Specificity and affinity of human $\mathrm{Fc} \gamma$ receptors and their polymorphic variants for human IgG subclasses. Blood. 113: 3716-3725.

128. Bolt, S., E. Routledge, I. Lloyd, L. Chatenoud, H. Pope, S. D. Gorman, M. Clark, and H. Waldmann (1993) The generation of a humanized, non-mitogenic CD3 monoclonal antibody which retains in vitro immunosuppressive properties. Eur. J. Immunol. 23: 403-411.

129. Leabman, M. K., Y. G. Meng, R. F. Kelley, L. E. DeForge, K. J. Cowan, and S. Iyer (2013) Effects of altered Fc $\gamma R$ binding on antibody pharmacokinetics in cynomolgus monkeys. MAbs. 5: 896-903.

130. Xu, D., M. L. Alegre, S. S. Varga, A. L. Rothermel, A. M. Collins, V. L. Pulito, L. S. Hanna, K. P. Dolan, P. W. Parren, J. A. Bluestone, L. K. Jolliffe, and R. A. Zivin (2000) In vitro characterization of five humanized OKT3 effector function variant antibodies. Cell Immunol. 200: 16-26.

131. An, Z., G. Forrest, R. Moore, M. Cukan, P. Haytko, L. Huang, S. Vitelli, J. Z. Zhao, P. Lu, J. Hua, C. R. Gibson, B. R. Harvey, D. Montgomery, D. Zaller, F. Wang, and W. Strohl (2009) IgG2m4, an engineered antibody isotype with reduced $\mathrm{Fc}$ function. MAbs. 1: 572-579.

132. Borrok, M. J., N. Mody, X. Lu, M. L. Kuhn, H. Wu, W. F. Dall'Acqua, and P. Tsui (2017) An "Fc-silenced" IgG1 format with extended half-life designed for improved stability. $J$. Pharm. Sci. 106: 1008-1017.

133. Stavenhagen, J. B., S. Gorlatov, N. Tuaillon, C. T. Rankin, H. Li, S. Burke, L. Huang, S. Vijh, S. Johnson, E. Bonvini, and S. Koenig (2007) Fc optimization of therapeutic antibodies enhances their ability to kill tumor cells in vitro and controls tumor expansion in vivo via low-affinity activating Fcy receptors. Cancer Res. 67: 8882-8890.

134. Shields, R. L., A. K. Namenuk, K. Hong, Y. G. Meng, J. Rae, J. Briggs, D. Xie, J. Lai, A. Stadlen, B. Li, J. A. Fox, and L. G. Presta (2001) High resolution mapping of the binding site on human IgG1 for Fc $\gamma$ RI, Fc $\gamma$ RII, Fc $\gamma$ RIII, and FcRn and design of IgG1 variants with improved binding to the Fc $\gamma \mathrm{R}$. J. Biol. Chem. 276: 6591-6604.

135. Idusogie, E. E., P. Y. Wong, L. G. Presta, H. Gazzano-Santoro, K. Totpal, M. Ultsch, and M. G. Mulkerrin (2001) Engineered antibodies with increased activity to recruit complement. $J$. Immunol. 166: 2571-2575.

136. Natsume, A., M. In, H. Takamura, T. Nakagawa, Y. Shimizu, K. Kitajima, M. Wakitani, S. Ohta, M. Satoh, K. Shitara, and R. Niwa (2008) Engineered antibodies of IgG1/IgG3 mixed isotype with enhanced cytotoxic activities. Cancer Res. 68: 3863-3872.

137. Jung, S. T., S. T. Reddy, T. H. Kang, M. J. Borrok, I. Sandlie, P. W. Tucker, and G. Georgiou (2010) Aglycosylated IgG variants expressed in bacteria that selectively bind FcyRI potentiate tumor cell killing by monocyte-dendritic cells. Proc. Natl. Acad. Sci. USA. 107: 604-609.

Publisher's Note Springer Nature remains neutral with regard to jurisdictional claims in published maps and institutional affiliations. 